\title{
Key gene regulatory sequences with distinctive ontological signatures associate with differentially endonuclease-accessible mouse sperm chromatin
}

\author{
Myriam Saida ${ }^{1}$, David Iles $^{2}$, Abdul Elnefati ${ }^{1}$, Martin Brinkworth ${ }^{3}$ and David Miller ${ }^{1}$ \\ ${ }^{1}$ Leeds Institute of Genetics, Health and Therapeutics, University of Leeds, Leeds, LS2 9JT, UK, ${ }^{2}$ Faculty of Biological \\ Sciences, Institute for Integrative and Comparative Biology, University of Leeds, Leeds, LS2 9JT, UK and ${ }^{3}$ Biomedical \\ Sciences, School of Life Sciences, University of Bradford, Richmond Building, Bradford, BD7 1DP, UK \\ Correspondence should be addressed to D Miller; Email: d.miller@leeds.ac.uk
}

\begin{abstract}
Using a well-established endonuclease-based chromatin dissection procedure in conjunction with both experimental comparative genome hybridisation (CGH) array profiling and in silico data mining, we show that mouse spermatozoa contain chromatin that is sensitive and resistant to digestion with micrococcal nuclease (MNase). Sequences represented in the micrococcal nuclease digestion solubilised (MNDS) but not the MND insoluble (MNDI) chromatin are strongly enriched in chromosomal regions of high gene density. Furthermore, by fluorescence in situ hybridisation (FISH) analysis, we show that MNDS and MNDI DNAs occupy distinct domains of decondensed mouse sperm nuclei that may also retain abundant histones. More detailed in silico analysis of $\mathrm{CGH}$ probe location in relation to known promoters and sequences recognised by CCCTC binding factor (CTCF) shows a significant excess of both in MNDS chromatin. A functional analysis of gene promoters reveals strong ontological signatures for ion transport on methylated promoters associated with CTCF binding sequences in MNDS chromatin. Sensory perception is the only strong ontological signature present in MNDI chromatin, driven by promoters that are not associated with CTCF regardless of their methylation status.
\end{abstract}

Reproduction (2011) 142 73-86

\section{Introduction}

Mammalian spermiogenesis is characterised by a fundamental reshaping of the spermatid that requires packaging the paternal genome in as small a volume as possible, which is believed to help in facilitating its transport to the egg and developing a transcriptionally silent, quiescent nucleus. To achieve this transformation, nucleosomes that form the normal packaging framework for nuclear DNA sequences are sequentially replaced first by transition proteins and then by nucleoprotamines (Tanphaichitr et al. 1978, Ward \& Coffey 1991, Braun 2001). Typically, mature mammalian sperm chromatin is at least ten times more condensed than that of the round spermatids from which they are derived (Powell et al. 1990). The protamines achieve this compaction by forming toroidal stacks that greatly increases DNA packaging density (Balhorn 2007). Once in the ooplasm, the paternal nucleus is quickly accessed by maternal factors that serve to decondense its chromatin in readiness for pronucleus formation and syngamy. During the course of these processes, protamines are completely stripped from paternal chromatin, substituted with maternal histones, and with the exception of imprinted sequences, paternal DNA is globally demethylated. Embryonic genome activation occurs sometime (always following the first cleavage stage) thereafter; (Collas \& Poccia 1998, McLay \& Clarke 2003, Santos et al. 2005).

Although the high compaction of sperm chromatin suggests that histones are completely replaced by protamines, there are a number of reports showing that a residual histone component is retained (Gatewood et al. 1990, Gardiner-Garden et al. 1998, Wykes \& Krawetz 2003, van der Heijden et al. 2006). Until recently, the purpose of the retention of nucleosomally packaged chromatin was unknown, but reasoning that it was likely to be more sensitive to digestion by exogenously applied endonucleases than the bulk nucleoprotamine, we treated detergent-extracted, decondensed and salt-washed human ejaculate and murine epididymal sperm nuclei with endonucleases (Arpanahi et al. 2009). As a result, we were able to demonstrate that solubilised human sperm chromatin was enriched in promoter sequences with a striking developmental ontology. An independent ChIP-based study on human 
sperm chromatin also reported similar findings showing that a developmental ontology was associated with promoters driving the expression of embryologically important genes that were marked with bivalent histone modification characteristics of pluripotency (Hammoud et al. 2009). Our own studies further showed that on a genome-wide scale, CCCTC binding factor (CTCF) binding sequences were also highly enriched in soluble human sperm chromatin, although adjacent genes did not exhibit a clear ontological signature.

In this study, we report the results of an equivalent study on mouse sperm chromatin and show that endonuclease-accessible and endonuclease-inaccessible DNAs locate to distinct 'territories' within decondensed mouse sperm nuclei. We further report that promoters in micrococcal nuclease (MNase)-accessible mouse sperm chromatin containing CTCF binding sites exhibit strong ontological profiles associated with cellular localisation, signalling and development.

\section{Results}

Comparative genome hybridisation, fluorescence in situ hybridisation, and immunocytochemistry (ICC)

Limited micrococcal nuclease digestion (MND) of murine epididymal sperm nuclei allowed us to generate MND soluble (MNDS) and MND insoluble (MNDI) chromatin fractions that were subjected to whole genome amplification (WGA) to generate the targets for comparative genome hybridisation $(\mathrm{CGH})$ microarray analysis and probes to examine sperm nuclei by fluorescence in situ hybridisation (FISH; as detailed in materials and methods). The S/I CGH profiles for chromosomes 4, 5, 7 and 14 are shown in Fig. 1 and demonstrate a clear association between solubility and gene density, particularly in gene-rich and gene-poor regions. Note, for example, the strong solubility or insolubility towards the telomeric ends of chromosomes 5 and 14 (bracketed regions), respectively, with islands of high or low gene density within these regions showing correspondingly high or low solubility (asterisks in Fig. 1D). As the MNDS fraction comprises a minor proportion of total mouse sperm chromatin $(<1.0 \%)$, profiles obtained from MNDS versus MNDI or MNDS versus undigested DNA should be qualitatively similar. Conversely, these profiles should be greatly flattened in comparisons between MNDI versus undigested DNA. To test these predictions, a 'virtual' undigested target was generated by combining probe MNDS- and MNDIprocessed intensity values from mouse sperm data and then modelling the $\mathrm{CGH} \log _{2} \mathrm{R}$ smoothed spline profiles in silico (see materials and methods). These are plotted for mouse chromosome 4 (Fig. 1E) and clearly show that insoluble and undigested targets behave similarly when compared with a soluble target. Moreover, these profiles are very similar to the original experimentally generated profile plotted in Fig. 1A and superimposed on Fig. 1E. In contrast, an almost flat profile is obtained from insoluble versus undigested DNA. These outcomes indicate that digestion-insoluble and undigested DNA generate essentially equivalent targets in these CGH-style experiments. Further supporting evidence for this conclusion is shown in Fig. 1F, which was generated from experimental comparisons between digested and undigested human sperm chromatin. In the example shown for chromosome 5, profiles obtained from digestion-soluble versus digestion-insoluble or undigested targets are virtually identical. These and the flat profiles from digestion-insoluble versus undigested targets are exactly as predicted by our in silico modelling and show that mouse and human sperm chromatin generate similar targets following limited endonuclease digestion.

The same target DNAs giving rise to the striking CGH patterns shown in Fig. 1A-D were then used to generate probes to examine their distribution in mouse sperm nuclei (Fig. 2); three representative fields of view are shown with the MNDS probe in green and the MNDI in red. They provide evidence for a differential location of the target sequences for these probes in decondensed mouse nuclei, with MNDS DNA located throughout nucleus but focused more strongly at the nuclear margins (panels A-C). MNDI DNA is also located throughout the nucleus but forms more concentrated regions within the nuclear interior (panels D-F). These features are particularly well highlighted when the images are merged (panels G-I). The diamidino-2-phenylindole (DAPI)stained DNA-only images (panels J-L) show a generally uniform chromatin distribution throughout the nucleus, with inter-nuclear differences in labelling intensity (for DAPI and corresponding probes) likely to result from different degrees of chromatin decondensation.

We then examined histone localisation in decondensed sperm nuclei using an anti-core histone antibody. In Fig. 3, two representative fields are shown. Panels A and $B$ indicate that histones are distributed throughout the nucleus, but that they are concentrated in the nuclear interior. The corresponding DAPI and merged images (panels C-F) show that DNA is uniformly labelled throughout the nucleus and suggest that the brighter interior signals mainly seen in panel $\mathrm{F}$ are due to the higher concentrations of histones therein. Other signals in these fields are from the decondensed nuclei of round cells in the squash preparations.

\section{Chromatin solubility in relation to promoter and CTCF binding}

Regulatory factors recognising promoters and other DNA binding sites (including the CTCF) play an important role in the control of gene expression. Moreover, CTCF is known to be closely involved in chromatin remodelling in somatic cells. We, therefore, explored whether the fractionation of these regulatory sequences might 


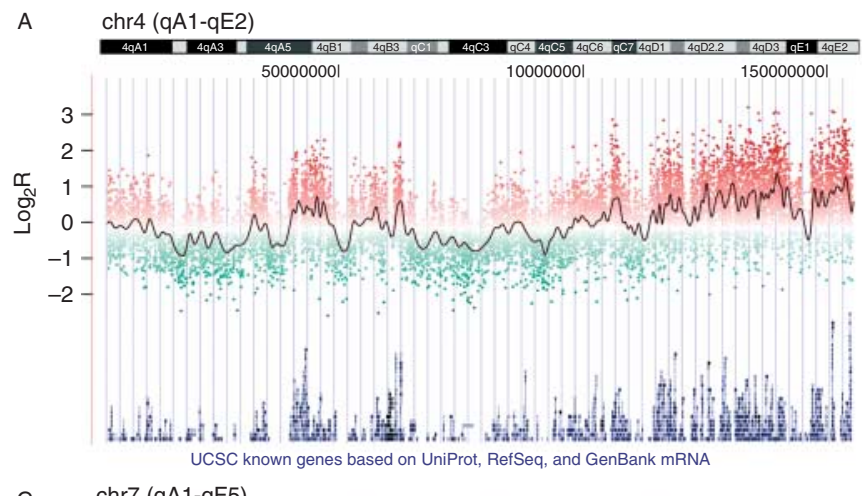

B $\operatorname{chr} 5(q A 1-q G 3)$
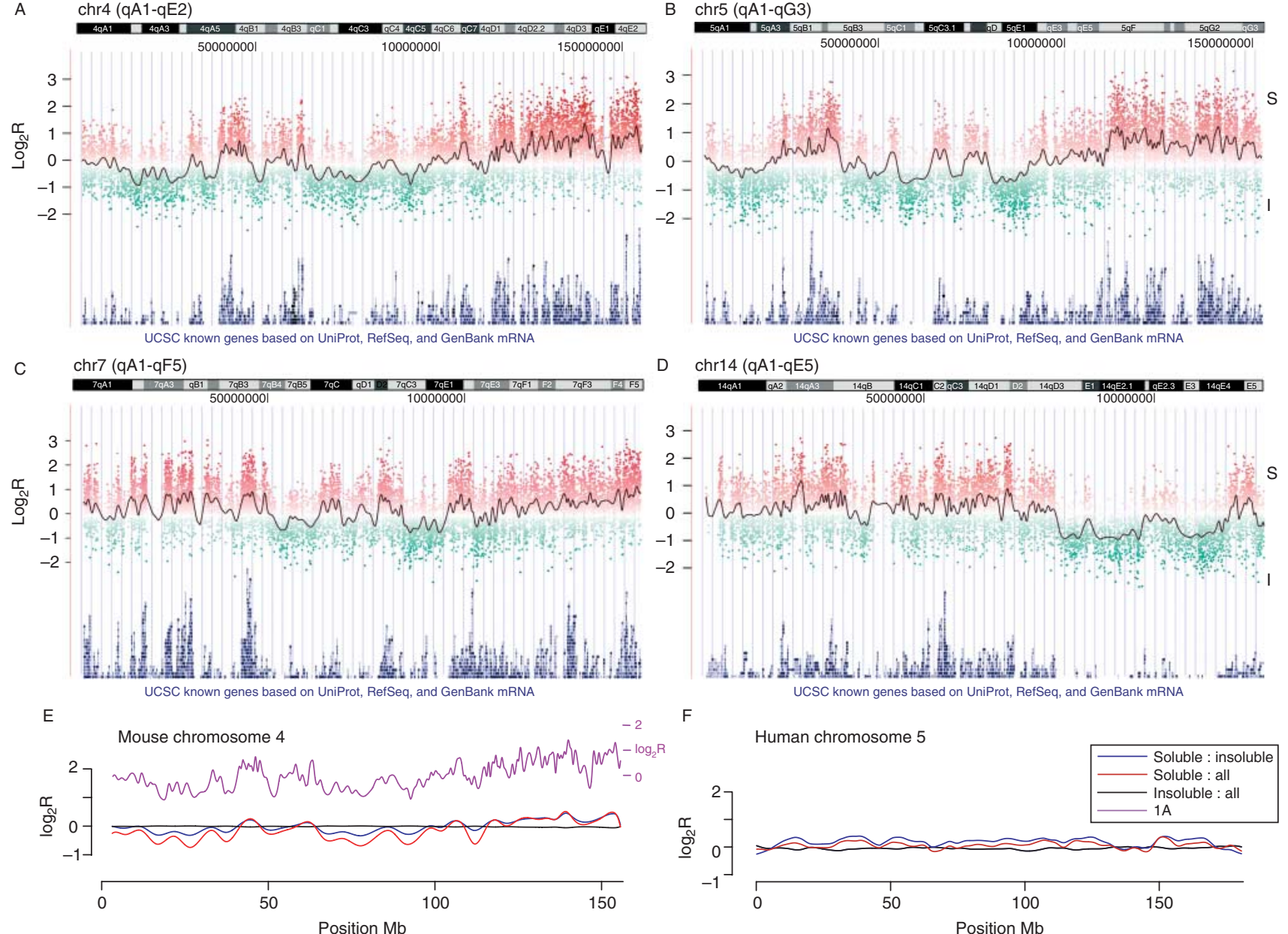

Figure 1 Whole chromosome CGH scatter plots. Examples for chromosomes 4 (A), 5 (B), 7 (C) and 14 (D) obtained from micrococcal nuclease digested $(\mathrm{MND})$ soluble $\left(\mathrm{S}\right.$; in red; $\log _{2}$ ratio $>0$ ) or insoluble $\left(\mathrm{I}\right.$; in green, $\log _{2}$ ratio $\left.<0\right)$ target fractions are shown together with smoothed spline plots. The RefSeq gene density profiles and chromosome ideograms are shown alongside for reference. Note the correspondence between the solubility and gene density profiles. Bracketed regions indicate generally soluble (B) or insoluble (D) regions with asterisks in D showing that soluble exceptions on 14E2 and 14E4 remain associated with gene clusters. In silico modelling of an undigested target from the mouse data is shown in (E). The spline points plotted here are equivalent to those shown in A-D and indicate that total and digestion-insoluble sperm chromatin are compositionally similar. The same is seen for human sperm, where experimental digestion was carried out (F). The experimentally derived spline points from mouse chromosome $4(\mathrm{~A})$ are superimposed at the top of $\mathrm{E}$.

provide clues to the purpose of differentially packaged domains in mammalian sperm chromatin. Previously, we looked at the distribution of promoter and CTCF binding sequences in human sperm chromatin and showed that both are more prevalent in the soluble DNA fractions (Arpanahi et al. 2009). The same also holds true for the mouse. Figure 4 summarises the results of an extended analysis examining the endonuclease partitioning behaviour of promoter and CTCF binding sequences in mouse sperm chromatin in relation to the strength of MND solubility. The median $\log _{2}$ ratio value for all promoter intervals in our dataset is 0.19, compared with 0.40 for all CTCF binding sequences (Table 1). As the median $\log _{2}$ ratio value for intergenic sequences is close to 0 , we conclude that promoters, particularly those associated with CTCF binding, are enriched in the MNDS fraction of mouse sperm chromatin. Table 1 also shows that as the extent of differential chromatin solubility increases $\left(\log _{2} R>0.5 /\right.$ $<-0.5$ and $>1.0 /<-1.0$ ), the enrichment of promoters containing CTCF binding sequences is correspondingly increased in MNDS chromatin.

\section{Ontological analysis}

The relatively high representation of promoter and CTCF binding sequences in our mouse MNDS dataset prompted us to investigate whether this was of ontological significance. The results are summarised in Table 2. We first examined the ontology of promoter intervals without CTCF binding sequences sorted by $\log _{2}$ ratios $\geq 0.5$ or $\leq-0.5$. We used DAVID's FAT category 

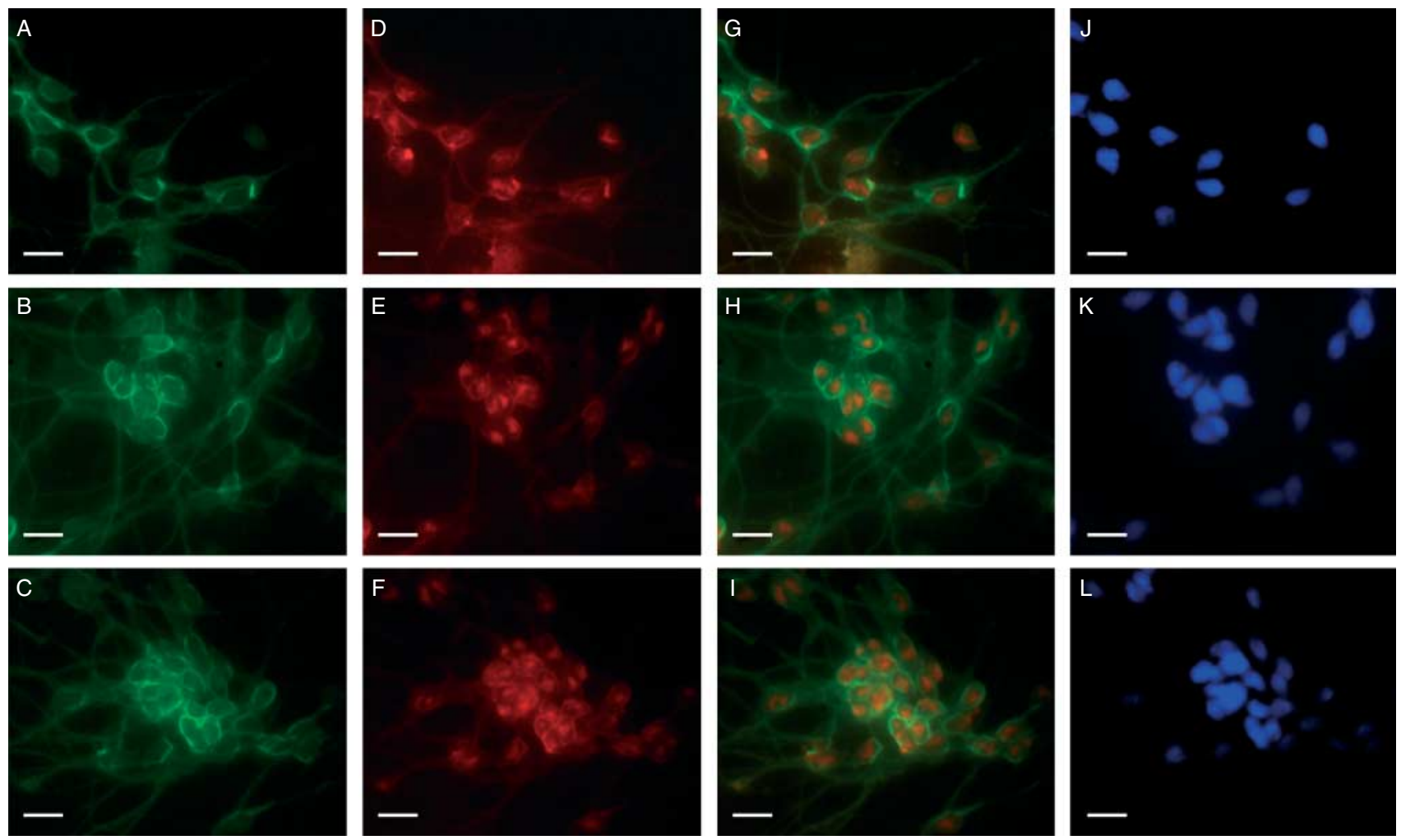

Figure 2 Whole sperm preps labelled by FISH. Probes for MNDS (A-C), MNDI (D-F) and merged MNDS+MNDI (G-I) are shown. DAPI only is shown in J-L. Note stronger peripheral labelling from MNDS probe and stronger, punctate, intra-nuclear labelling from MNDI probe. Scale bar is $10 \mu \mathrm{M}$.

for bioprocess, which essentially provides a summary of significant ontologies across all five gene ontology (GO) levels (the ALL category is also provided for comparison). Following submission of gene lists to the DAVID server, the MNDS ${ }^{\mathrm{CTCF}-}$ fraction returned a weak enrichment for promoters driving the expression of genes involved in differentiation and development (Table 2). In contrast, The MNDI ${ }^{\mathrm{CTCF}-}$ fraction returned a strong enrichment of promoters driving genes involved in sensory perception and signalling. We repeated the test with promoter intervals containing one or more CTCF binding sequences and found the MNDS ${ }^{\mathrm{CTCF}+}$ fraction strongly enriched for genes involved in ion transport, while the $\mathrm{MNDI}^{\mathrm{CTCF}+}$-fraction returned nothing of significance.

As DNA methylation plays a crucial role in the control of gene expression, we determined whether methylation status affects the packaging preferences of spermatozoal chromatin and the ontology of genes in each fraction. We found methylated DNA to be slightly enriched in MNDS chromatin $\left(r_{\mathrm{s}}=0.17\right.$, $P<0.0001)$. Methylated promoters in the MNDS fraction lacking CTCF binding sequences returned only a weak ontological signature for genes involved in wound healing. Those in the MNDI fraction returned the same sensory ontology as all MNDI promoters, albeit more weakly. Hypomethylated promoters in the MNDS fraction returned a weak developmental ontology compared with a weaker sensory ontology for those in the MNDI fraction. Promoter intervals associated with CTCF binding sites gave contrasting results with the ion transport and the sensory ontologies restricted, respectively, to MNDS $\mathrm{CTCF}^{\mathrm{C}}, 5 \mathrm{mC}+$ and $\mathrm{MNDI}^{\mathrm{CTCF}-}$, $5 \mathrm{mC}+$ chromatin. No significant ontology was apparent in either of the corresponding MNDS ${ }^{\mathrm{CTCF}+}, 5 \mathrm{mC}-$ or $\mathrm{MNDI}^{\mathrm{CTCF}+, 5 \mathrm{mC}+}$ chromatin.

\section{Discussion}

The mammalian spermatozoon is exquisitely specialised to deliver the paternal genome to the egg, and in order to achieve this goal as efficiently as possible, its DNA is compacted at least tenfold over that observed in earlier developing spermatids (Powell et al. 1990). However, even though sperm chromatin is highly condensed there is evidence that it is also highly organised, with the location of domains that contain particular chromosomal regions being conserved from sperm to sperm (Zalensky et al. 1995, Hazzouri et al. 2000). Recent work also suggests that regions accessible to exogenously applied endonucleases contain sequences that differ in gene composition from the bulk chromatin. Gatewood et al. (1987) for example, showed that globin isoforms expressed in the early embryo are packaged in nuclease-accessible regions and Wykes \& 

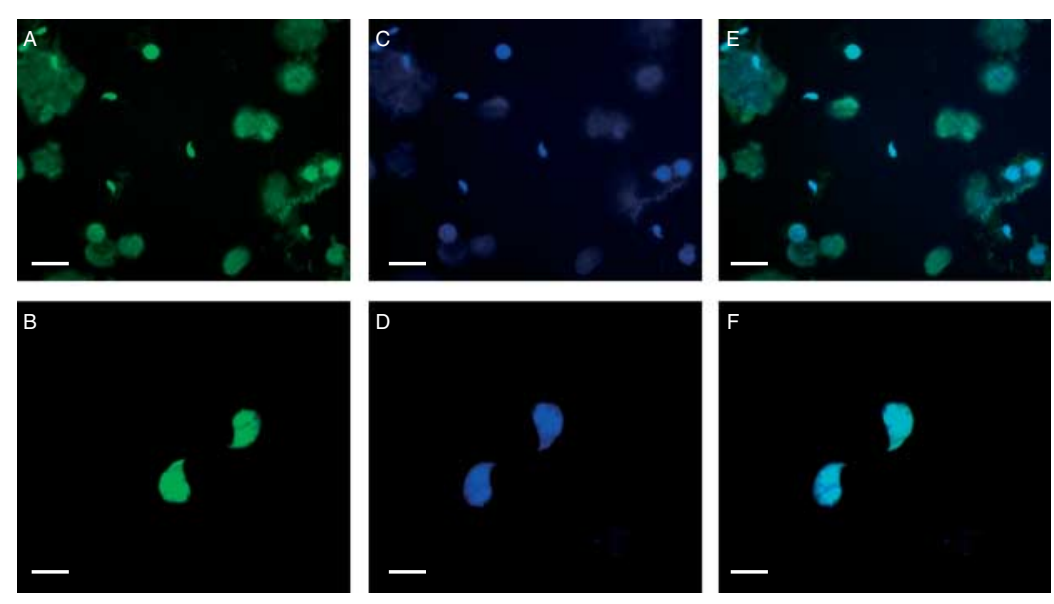

Figure 3 Sperm nuclei labelled by immunofluorescence with a core anti-histone antibody (A and B); DAPI only (C and D) and merged antibody + DAPI (E and F). Scale bar is $20 \mu \mathrm{m}$ (A, C, and E) or $10 \mu \mathrm{m}$ $(B, D$, and $F)$. Note punctate labelling /staining in $B$ and $D$. The more diffuse signals in these fields are from the decondensed nuclei of round cells in these squash preparations.
Krawetz (2003) found marked differences in packaging preference within and between the main genes in the protamine-transition protein gene cluster. Both reports alluded to the likelihood of these nuclease-accessible regions being packaged by the residual nucleosomes of sperm chromatin, previously shown to exist by biochemical and biophysical studies (Gatewood et al. 1990, Hud et al. 1993, Allen et al. 1996, Gardiner-Garden et al. 1998, Brewer et al. 1999, 2003, Nazarov et al. 2008).

In our earlier report focusing on human sperm chromatin (Arpanahi et al. 2009), we showed that clear and highly reproducible similarities exist in the populations of DNA sequences released from both SRD- and MNase-treated chromatin, with genic sequences being enriched in solubilised chromatin. We further showed that promoter and CTCF binding sequences were significantly more abundant in solubilised chromatin in comparison with insoluble chromatin. Importantly, the promoters represented in the soluble fraction controlled the expression of genes exhibiting a strong ontological signature for early developmental processes. A related report (Hammoud et al. 2009) used a ChIP-seq strategy and also showed that human sperm histones bound sequences with a strong early developmental ontology and further a sub-fraction contained chromatin with a bivalent motif of histone modifications typical of pluripotent stem cells. Extending this work, we confirm here that just as in humans, chromosomal regions of high gene density are strongly represented in MNaseaccessible mouse sperm chromatin (Fig. 1). In addition, we show that promoter and CTCF binding sequences, rather than genic sequences per se, are enriched in the soluble fraction (Fig. 4). Furthermore, we have demonstrated that the olfactory gene clusters (the most abundant gene family of both species (Crasto et al. 2002)) are predominantly present in the insoluble sperm chromatin of both humans and mice. These findings together indicate that the organisation of chromatin in mammalian male gametes is consistent between primates and rodents and this may reflect a high degree of evolutionary conservation, which in turn indicates a profound functional significance.

To investigate the possibility that digestion-soluble and insoluble chromatin might occupy different regions within the mouse sperm nucleus, MNDS and MNDI fractions were labelled and used to probe decondensed mouse sperm nuclei. Figure 2 shows that while both DNAs are distributed throughout the nucleus, clear differences exist in their respective distribution. MNDS DNA is predominantly located around the nuclear periphery. Although the MNDI probe hybridised to some extent with sequences located around the nuclear periphery of many cells, hybridisation was strongly focused on structures within the nucleus. In this regard, MNDS labelling resembles that obtained by

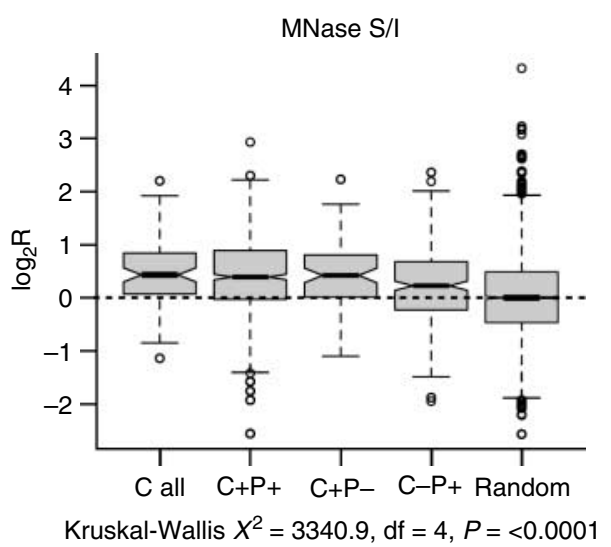

Figure 4 Gene regulatory sequences in mouse sperm MNDS/MNDI fractions. Boxplots showing the partitioning behaviour of all sequences containing CTCF binding sites (C all) or in association with promoter sequences $(\mathrm{C}+\mathrm{P}+)$ or not associated with promoter sequences $(\mathrm{C}+\mathrm{P}-)$. Plots for all promoters not associated with CTCF binding sequences $(\mathrm{C}-\mathrm{P}+)$ and a randomly selected set of targets (random) are also shown. The centre of the boxes indicates the median values with the first and third quartiles drawn on either side. Notches indicate significant differences in median values (Tukey's honest significant difference). In these plots, $\log _{2}$ ratio values $>0$ indicate solubility and $<0$ indicate insolubility. 


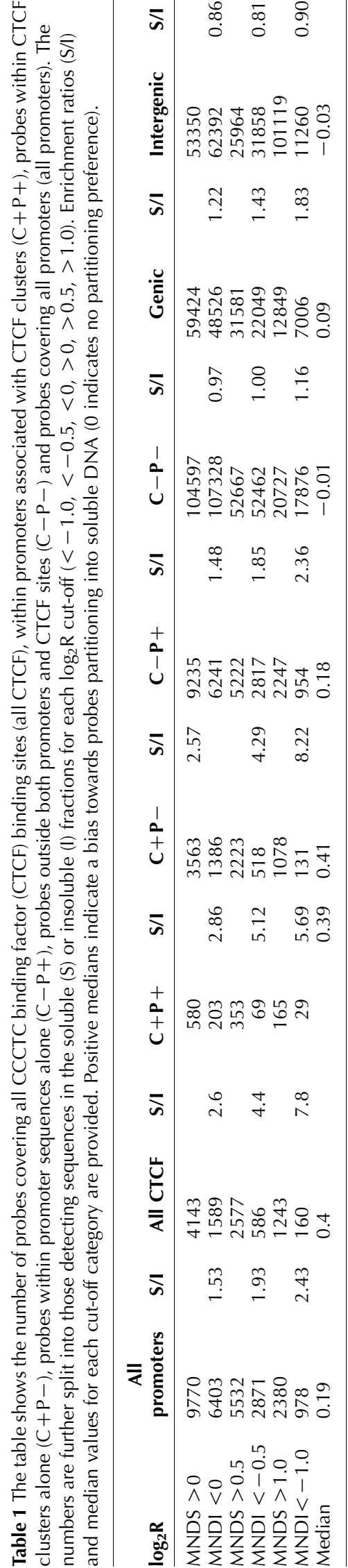

immunocytochemical analysis of mouse sperm using antibodies to H1 (Pittoggi et al. 1999), while the MNDI labelling resembles the variant histone-enriched pericentromeric heterochromatin reported by Govin et al. (2007) and Van der Heijden et al. (2006). Similar structures have been reported in human spermatozoa using centromeric FISH probes (Hazzouri et al. 2000) and antibodies to the sperm-specific CENP-A histone variant in bovine spermatozoa (Palmer et al. 1990). In support of these observations, our current work shows that an antibody to core histones decorated similar intra-nuclear structures (Fig. 3).

We estimated that $\sim 0.6$ and $12 \% \mathrm{w} / \mathrm{w}$ of mouse and human sperm chromatin could be digested by endonucleases. These values are in broad agreement with independent estimates for nucleosomal chromatin in sperm nuclei (Gardiner-Garden et al. 1998, Pittoggi et al. 1999), suggesting that digested chromatin is enriched with histones. Indeed, we previously showed that nucleosomal ladders could be generated from human sperm chromatin by limited digestion with MNase (Arpanahi et al. 2009). While the results of our FISH study suggest that MNDS chromatin is located at the nuclear periphery, our immunofluorescence (IFL) data suggest that histones are more widely distributed in the nucleus and may be more abundant at deeper levels. The simplest interpretation of the differing FISH and IFL localisations is that peripherally located chromatin is more accessible to endonuclease digestion and so gives rise to probes that preferentially recognise that region (Fig. 5). Nevertheless, the striking ontological signature of MNDS chromatin argues against this being without physiological significance. Rather, our findings suggest that the relative difference in the prevalence of regulatory sequences in fractionated mouse sperm chromatin reflects their preferential location in distinct geographical 'territories' within the nucleus and in this case closer to the nuclear periphery. CTCF is closely involved in establishing gene imprints and in the demarcation of chromatin boundaries (Ohlsson et al. 2001, Chen et al. 2006, Phillips \& Corces 2009). Therefore, the relatively high representation of its binding sites in peripherally located MNDS fractions suggests that CTCF may itself play a role in establishing these domains during sperm differentiation.

Unlike the human, soluble promoters per se from mouse sperm chromatin do not show a strong ontological signature, although insoluble promoters show the same strong ontology for sensory perception. Instead, it is the association of soluble promoters with CTCF binding sites that appears to drive the ontological signature in mouse sperm chromatin (Tables 2 and 3 ). In contrast, the presence of CTCF binding sites in insoluble promoters abolishes the MNDI sensory ontology altogether. These data suggest the existence of two sub-domains of promoter packaging, dependent on their association with CTCF binding sites and on their 
Table 2 Probes associated with promoter sequences returning $\log _{2} R$ values $>0.5$ or $<-0.5$ were submitted to the DAVID Gene Ontology web server at http://david.abcc.ncifcrf.gov/ against a background list of the human genome. Only the top five bioprocess 'FAT' category following Benjamini correction is shown for the target categories and sorted by false discovery rate (FDR). Significantly enriched categories are shown in bold and based on both Benjamini $P$ value and the number of genes in each category.

\begin{tabular}{|c|c|c|c|c|c|c|c|}
\hline Term & Count & $\begin{array}{l}\text { Percentage } \\
\quad(\%)\end{array}$ & $P$ value & $\begin{array}{c}\text { Fold } \\
\text { enrichment }\end{array}$ & Bonferroni & Benjamini & FDR \\
\hline \multicolumn{8}{|l|}{$\mathrm{C}-\mathrm{MNDS}$} \\
\hline GO:0030182 neuron differentiation & 56 & 4.19 & $2.79 \times 10^{-5}$ & 1.79 & $8.49 \times 10^{-2}$ & $8.49 \times 10^{-2}$ & $5.05 \times 10^{-2}$ \\
\hline GO:0006955 immune response & 62 & 4.64 & $6.77 \times 10^{-5}$ & 1.67 & $1.94 \times 10^{-1}$ & $1.02 \times 10^{-1}$ & $1.23 \times 10^{-1}$ \\
\hline GO:0021536 diencephalon development & 12 & 0.90 & $1.11 \times 10^{-4}$ & 4.02 & $2.97 \times 10^{-1}$ & $1.11 \times 10^{-1}$ & $2.00 \times 10^{-1}$ \\
\hline GO:0009611 response to wounding & 48 & 3.59 & $1.60 \times 10^{-4}$ & 1.76 & $3.99 \times 10^{-1}$ & $1.20 \times 10^{-1}$ & $2.90 \times 10^{-1}$ \\
\hline GO:0006954 inflammatory response & 35 & 2.62 & $1.63 \times 10^{-4}$ & 1.98 & $4.05 \times 10^{-1}$ & $9.87 \times 10^{-2}$ & $2.95 \times 10^{-1}$ \\
\hline \multicolumn{8}{|l|}{$\mathrm{C}-\mathrm{MNDI}$} \\
\hline $\begin{array}{l}\text { GO:0007606 sensory perception of chemical } \\
\text { stimulus }\end{array}$ & 63 & 16.20 & $1.03 \times 10^{-9}$ & 2.27 & $1.51 \times 10^{-6}$ & $1.51 \times 10^{-6}$ & $1.70 \times 10^{-6}$ \\
\hline $\begin{array}{l}\text { GO:0007186 G-protein coupled receptor } \\
\text { protein signalling pathway }\end{array}$ & 84 & 21.59 & $2.35 \times 10^{-9}$ & 1.92 & $3.47 \times 10^{-6}$ & $1.74 \times 10^{-6}$ & $3.90 \times 10^{-6}$ \\
\hline GO:0007608 sensory perception of smell & 57 & 14.65 & $2.81 \times 10^{-8}$ & 2.19 & $4.16 \times 10^{-5}$ & $1.39 \times 10^{-5}$ & $4.67 \times 10^{-5}$ \\
\hline $\begin{array}{l}\text { GO:0007166 cell surface receptor linked } \\
\text { signal transduction }\end{array}$ & 98 & 25.19 & $5.60 \times 10^{-8}$ & 1.68 & $8.28 \times 10^{-5}$ & $2.07 \times 10^{-5}$ & $9.29 \times 10^{-5}$ \\
\hline GO:0007600 sensory perception & 64 & 16.45 & $1.93 \times 10^{-7}$ & 1.96 & $2.86 \times 10^{-4}$ & $5.71 \times 10^{-5}$ & $3.21 \times 10^{-4}$ \\
\hline \multicolumn{8}{|l|}{$C+$ MNDS } \\
\hline GO:0006811 ion transport & 93 & 8.71 & $1.52 \times 10^{-10}$ & 1.99 & $4.72 \times 10^{-7}$ & $4.72 \times 10^{-7}$ & $2.75 \times 10^{-7}$ \\
\hline GO:0006812 cation transport & 70 & 6.55 & $7.93 \times 10^{-9}$ & 2.08 & $2.46 \times 10^{-5}$ & $1.23 \times 10^{-5}$ & $1.43 \times 10^{-5}$ \\
\hline GO:0006816 calcium ion transport & 26 & 2.43 & $2.22 \times 10^{-7}$ & 3.28 & $6.89 \times 10^{-4}$ & $2.30 \times 10^{-4}$ & $4.02 \times 10^{-4}$ \\
\hline GO:0030001 metal ion transport & 59 & 5.52 & $2.65 \times 10^{-7}$ & 2.04 & $8.22 \times 10^{-4}$ & $2.06 \times 10^{-4}$ & $4.79 \times 10^{-4}$ \\
\hline GO:0044057 regulation of system process & 35 & 3.28 & $2.76 \times 10^{-7}$ & 2.66 & $8.55 \times 10^{-4}$ & $1.71 \times 10^{-4}$ & $4.98 \times 10^{-4}$ \\
\hline \multicolumn{8}{|l|}{$\mathrm{C}+\mathrm{MNDI}$} \\
\hline GO:0019226 transmission of nerve impulse & 9 & 5.06 & $2.81 \times 10^{-3}$ & 3.73 & $9.55 \times 10^{-1}$ & $9.55 \times 10^{-1}$ & 4.40 \\
\hline GO:0007268 synaptic transmission & 8 & 4.49 & $2.87 \times 10^{-3}$ & 4.21 & $9.58 \times 10^{-1}$ & $7.96 \times 10^{-1}$ & 4.50 \\
\hline GO:0007267 cell-cell signalling & 10 & 5.62 & $3.75 \times 10^{-3}$ & 3.23 & $9.84 \times 10^{-1}$ & $7.49 \times 10^{-1}$ & 5.83 \\
\hline GO:0060284 regulation of cell development & 7 & 3.93 & $6.93 \times 10^{-3}$ & 4.13 & 1.00 & $8.53 \times 10^{-1}$ & $1.05 \times 10^{1}$ \\
\hline GO:0050767 regulation of neurogenesis & 6 & 3.37 & $1.32 \times 10^{-2}$ & 4.26 & 1.00 & $9.47 \times 10^{-1}$ & $1.91 \times 10^{1}$ \\
\hline \multicolumn{8}{|l|}{$\mathrm{C}-5 \mathrm{mC}+\mathrm{MNDS}$} \\
\hline GO:0009611 response to wounding & 33 & 4.78 & $7.88 \times 10^{-6}$ & 2.40 & $1.79 \times 10^{-2}$ & $1.79 \times 10^{-2}$ & $1.38 \times 10^{-2}$ \\
\hline GO:0006954 inflammatory response & 24 & 3.47 & $3.03 \times 10^{-5}$ & 2.69 & $6.71 \times 10^{-2}$ & $3.42 \times 10^{-2}$ & $5.29 \times 10^{-2}$ \\
\hline GO:0006955 immune response & 38 & 5.50 & $5.67 \times 10^{-5}$ & 2.03 & $1.22 \times 10^{-1}$ & $4.25 \times 10^{-2}$ & $9.91 \times 10^{-2}$ \\
\hline GO:0006952 defense response & 36 & 5.21 & $9.83 \times 10^{-5}$ & 2.03 & $2.02 \times 10^{-1}$ & $5.49 \times 10^{-2}$ & $1.72 \times 10^{-1}$ \\
\hline GO:0007601 visual perception & 14 & 2.03 & $1.70 \times 10^{-4}$ & 3.49 & $3.24 \times 10^{-1}$ & $7.53 \times 10^{-2}$ & $2.97 \times 10^{-1}$ \\
\hline \multicolumn{8}{|l|}{$C-5 \mathrm{mC}+\mathrm{MNDI}$} \\
\hline $\begin{array}{l}\text { GO:0007186 } \sim \text { G-protein coupled receptor } \\
\text { protein signalling pathway }\end{array}$ & 34 & 26.77 & $9.93 \times 10^{-7}$ & 2.41 & $6.31 \times 10^{-4}$ & $6.31 \times 10^{-4}$ & $1.48 \times 10^{-3}$ \\
\hline $\begin{array}{l}\text { GO:0007606 sensory perception of chemical } \\
\text { stimulus }\end{array}$ & 26 & 20.47 & $1.40 \times 10^{-6}$ & 2.91 & $8.87 \times 10^{-4}$ & $4.44 \times 10^{-4}$ & $2.08 \times 10^{-3}$ \\
\hline GO:0007608 sensory perception of smell & 23 & 18.11 & $1.88 \times 10^{-5}$ & 2.74 & $1.18 \times 10^{-2}$ & $3.96 \times 10^{-3}$ & $2.79 \times 10^{-2}$ \\
\hline GO:0007600 sensory perception & 26 & 20.47 & $2.46 \times 10^{-5}$ & 2.47 & $1.55 \times 10^{-2}$ & $3.90 \times 10^{-3}$ & $3.66 \times 10^{-2}$ \\
\hline $\begin{array}{l}\text { GO:0007166 cell surface receptor linked } \\
\text { signal transduction }\end{array}$ & 37 & 29.13 & $2.76 \times 10^{-5}$ & 1.98 & $1.74 \times 10^{-2}$ & $3.50 \times 10^{-3}$ & $4.10 \times 10^{-2}$ \\
\hline \multicolumn{8}{|l|}{$C-5 \mathrm{mC}-\mathrm{MNDS}$} \\
\hline GO:0030182 neuron differentiation & 38 & 6.25 & $2.04 \times 10^{-7}$ & 2.59 & $4.76 \times 10^{-4}$ & $4.76 \times 10^{-4}$ & $3.58 \times 10^{-4}$ \\
\hline GO:0048663 neuron fate commitment & 11 & 1.81 & $6.10 \times 10^{-6}$ & 6.37 & $1.41 \times 10^{-2}$ & $7.08 \times 10^{-3}$ & $1.07 \times 10^{-2}$ \\
\hline GO:0045165 cell fate commitment & 19 & 3.13 & $7.13 \times 10^{-6}$ & 3.52 & $1.65 \times 10^{-2}$ & $5.52 \times 10^{-3}$ & $1.25 \times 10^{-2}$ \\
\hline GO:0007389 pattern specification process & 27 & 4.44 & $1.70 \times 10^{-5}$ & 2.59 & $3.88 \times 10^{-2}$ & $9.85 \times 10^{-3}$ & $2.98 \times 10^{-2}$ \\
\hline GO:0003002 regionalisation & 21 & 3.45 & $1.19 \times 10^{-4}$ & 2.67 & $2.42 \times 10^{-1}$ & $5.39 \times 10^{-2}$ & $2.08 \times 10^{-1}$ \\
\hline \multicolumn{8}{|l|}{$\mathrm{C}-5 \mathrm{mC}-\mathrm{MNDI}$} \\
\hline $\begin{array}{l}\text { GO:0007606 sensory perception of chemical } \\
\text { stimulus }\end{array}$ & 36 & 14.63 & $5.19 \times 10^{-5}$ & 2.05 & $6.07 \times 10^{-2}$ & $6.07 \times 10^{-2}$ & $8.40 \times 10^{-2}$ \\
\hline GO:0007608 sensory perception of smell & 33 & 13.41 & $1.80 \times 10^{-4}$ & 2.01 & $1.95 \times 10^{-1}$ & $1.03 \times 10^{-1}$ & $2.90 \times 10^{-1}$ \\
\hline $\begin{array}{l}\text { GO:0007166 cell surface receptor linked } \\
\text { signal transduction }\end{array}$ & 58 & 23.58 & $2.39 \times 10^{-4}$ & 1.58 & $2.50 \times 10^{-1}$ & $9.14 \times 10^{-2}$ & $3.85 \times 10^{-1}$ \\
\hline $\begin{array}{l}\text { GO:0007186 } \sim \text { G-protein coupled receptor } \\
\text { protein signalling pathway }\end{array}$ & 47 & 19.11 & $2.46 \times 10^{-4}$ & 1.70 & $2.56 \times 10^{-1}$ & $7.14 \times 10^{-2}$ & $3.97 \times 10^{-1}$ \\
\hline GO:0007600 sensory perception & 37 & 15.04 & $5.70 \times 10^{-4}$ & 1.79 & $4.97 \times 10^{-1}$ & $1.28 \times 10^{-1}$ & $9.19 \times 10^{-1}$ \\
\hline \multicolumn{8}{|l|}{$C+5 \mathrm{mC}+\mathrm{MNDS}$} \\
\hline GO:0006811 ion transport & 61 & 10.41 & $3.12 \times 10^{-10}$ & 2.41 & $7.57 \times 10^{-7}$ & $7.57 \times 10^{-7}$ & $5.48 \times 10^{-7}$ \\
\hline GO:0006812 cation transport & 47 & 8.02 & $7.32 \times 10^{-9}$ & 2.57 & $1.78 \times 10^{-5}$ & $8.88 \times 10^{-6}$ & $1.29 \times 10^{-5}$ \\
\hline GO:0030001 metal ion transport & 38 & 6.48 & $1.15 \times 10^{-6}$ & 2.42 & $2.79 \times 10^{-3}$ & $9.30 \times 10^{-4}$ & $2.02 \times 10^{-3}$ \\
\hline GO:0006816 calcium ion transport & 17 & 2.90 & $5.67 \times 10^{-6}$ & 3.95 & $1.37 \times 10^{-2}$ & $3.43 \times 10^{-3}$ & $9.96 \times 10^{-3}$ \\
\hline GO:0055085 transmembrane transport & 36 & 6.14 & $1.82 \times 10^{-5}$ & 2.20 & $4.33 \times 10^{-2}$ & $8.81 \times 10^{-3}$ & $3.21 \times 10^{-2}$ \\
\hline \multicolumn{8}{|l|}{$\mathrm{C}+5 \mathrm{mC}+\mathrm{MNDI}$} \\
\hline GO:0007155 cell adhesion & 9 & & $7.04 \times 10^{-4}$ & 4.45 & $3.09 \times 10^{-1}$ & $3.09 \times 10^{-1}$ & 1.02 \\
\hline GO:0022610 biological adhesion & 9 & 13.85 & $7.12 \times 10^{-4}$ & 4.44 & $3.12 \times 10^{-1}$ & $1.70 \times 10^{-1}$ & 1.03 \\
\hline
\end{tabular}


Table 2 Continued.

\begin{tabular}{|c|c|c|c|c|c|c|c|}
\hline Term & Count & $\begin{array}{l}\text { Percentage } \\
\qquad(\%)\end{array}$ & $P$ value & $\begin{array}{l}\text { Fold } \\
\text { enrichment }\end{array}$ & Bonferroni & Benjamini & FDR \\
\hline GO:0019226 transmission of nerve impulse & 6 & 9.23 & $1.16 \times 10^{-3}$ & 7.36 & $4.57 \times 10^{-1}$ & $1.84 \times 10^{-1}$ & 1.68 \\
\hline GO:0007268 synaptic transmission & 5 & 7.69 & $3.54 \times 10^{-3}$ & 7.79 & $8.44 \times 10^{-1}$ & $3.71 \times 10^{-1}$ & 5.00 \\
\hline GO:0007269 neurotransmitter secretion & 3 & 4.62 & $7.13 \times 10^{-3}$ & 23.11 & $9.76 \times 10^{-1}$ & $5.28 \times 10^{-1}$ & 9.85 \\
\hline \multicolumn{8}{|l|}{$C+5 \mathrm{mC}-\mathrm{MNDS}$} \\
\hline $\begin{array}{l}\text { GO:0051969 } \sim \text { regulation of transmission of } \\
\text { nerve impulse }\end{array}$ & 13 & 2.84 & $5.46 \times 10^{-5}$ & 4.23 & $1.05 \times 10^{-1}$ & $1.05 \times 10^{-1}$ & $9.40 \times 10^{-2}$ \\
\hline $\begin{array}{l}\text { GO:0031644 regulation of neurological } \\
\text { system process }\end{array}$ & 13 & 2.84 & $9.34 \times 10^{-5}$ & 4.01 & $1.72 \times 10^{-1}$ & $9.01 \times 10^{-2}$ & $1.61 \times 10^{-1}$ \\
\hline $\begin{array}{l}\text { GO:0050804 regulation of synaptic trans- } \\
\text { mission }\end{array}$ & 12 & 2.63 & $1.33 \times 10^{-4}$ & 4.18 & $2.35 \times 10^{-1}$ & $8.55 \times 10^{-2}$ & $2.28 \times 10^{-1}$ \\
\hline GO:0044057 regulation of system process & 17 & 3.72 & $2.20 \times 10^{-4}$ & 2.95 & $3.59 \times 10^{-1}$ & $1.05 \times 10^{-1}$ & $3.77 \times 10^{-1}$ \\
\hline $\begin{array}{l}\text { GO:0006468 protein amino acid phos- } \\
\text { phorylation }\end{array}$ & 35 & 7.66 & $3.83 \times 10^{-4}$ & 1.91 & $5.39 \times 10^{-1}$ & $1.43 \times 10^{-1}$ & $6.57 \times 10^{-1}$ \\
\hline \multicolumn{8}{|l|}{$\mathrm{C}+5 \mathrm{mC}-\mathrm{MNDI}$} \\
\hline $\begin{array}{l}\text { GO:0000904 cell morphogenesis involved in } \\
\text { differentiation }\end{array}$ & 6 & 5.77 & $1.16 \times 10^{-2}$ & 4.37 & 1.00 & 1.00 & $1.63 \times 10^{1}$ \\
\hline GO:0006281 DNA repair & 6 & 5.77 & $1.39 \times 10^{-2}$ & 4.17 & 1.00 & $9.95 \times 10^{-1}$ & $1.92 \times 10^{1}$ \\
\hline GO:0000902 cell morphogenesis & 7 & 6.73 & $1.43 \times 10^{-2}$ & 3.50 & 1.00 & $9.73 \times 10^{-1}$ & $1.97 \times 10^{1}$ \\
\hline GO:0001568 blood vessel development & 6 & 5.77 & $2.01 \times 10^{-2}$ & 3.80 & 1.00 & $9.78 \times 10^{-1}$ & $2.66 \times 10^{1}$ \\
\hline GO:0007409 axonogenesis & 5 & 4.81 & $2.06 \times 10^{-2}$ & 4.74 & 1.00 & $9.56 \times 10^{-1}$ & $2.71 \times 10^{1}$ \\
\hline
\end{tabular}

relative solubility. This striking difference between human and mouse sperm chromatin is not due to the source of CTCF binding data, which were derived from a mesenchymal fibroblast and embryonic stem (ES) cell source in human (Kim et al. 2007) and mouse (Chen et al. 2008) respectively. We know this because repeating the human analysis with a CTCF binding data set obtained from a human ES source (http://hgdownload-test.cse.ucsc. edu/goldenPath/hg18/encodeDCC.00/wgEncodeBroad ChipSeq/wgEncodeBroadChipSeqPeaksH1 hescCtcf. broadPeak.gz) did not change the lack of ontology in human promoters associated with CTCF binding sites (data not shown).

The high enrichment of Olfr promoter sequences in the MNDI fraction is also noteworthy, as this group of highly abundant genes was shown to be hypermethylated in human fibroblast and sperm cell nuclei (Weber et al. 2007). In comparison, Hammoud et al. (2009) found evidence that the promoters of other, developmentally important genes were both hypermethylated and hypomethylated in human sperm chromatin, including several HOX gene clusters. Mouse Hox gene clusters are mostly methylated (Farthing et al. 2008) and, unlike the human orthologues, show a more mixed pattern of endonuclease sensitivity and insensitivity (data not shown). Using the MeDIP data from Farthing et al. (2008), we examined the influence of methylation status on the ontological categories uncovered in this study. The ion transport ontology of soluble chromatin associated with CTCF binding was abolished in hypomethylated DNA, indicating that ontologically significant CTCF-containing sequences are methylated in soluble mouse sperm chromatin (Tables 2 and 3). In the absence of CTCF binding sites, however, a relatively strong signature for neuronal differentiation was revealed in soluble, hypomethylated DNA. These data suggest an almost inverse relationship between CTCF binding and DNA methylation in MNDS chromatin. Hence, significant ontology in the MNDS chromatin seems to require methylated DNA in the presence of CTCF binding sites and demethylated DNA in its absence. Our data suggest that ontology in the MNDI chromatin requires mostly demethylated DNA in the absence of CTCF binding sites; the presence of CTCF binding sites is not associated with any gene ontology regardless of methylation status. These findings concur with those of another report, which commented on the mutual exclusiveness of histone (H3K4) and DNA methylation in human sperm chromatin and on the relative importance of H3K27 trimethylation in potentially carrying a developmental ontological signature to the oocyte (Brykczynska et al. 2010). Both the neuronal and the sensory ontologies found, respectively, in (demethylated) MNDS and MNDI mouse sperm chromatin lacking CTCF binding sequences respectively, are closely related to the developmental and sensory ontologies found in human MNDS and MNDI sperm chromatin, respectively, (Arpanahi et al. 2009) and the developmental ontology associated with (demethylated DNA) H3K27 trimethylation of human and mouse sperm (Brykczynska et al. 2010). Moreover, ion transport is critical for normal spermatozoal function during capacitation and fertilisation (Breitbart 2003) and its associated genes are expressed during spermiogensis. In the Brykcznska study, a related ontology was reported for sperm chromatin carrying genes involved in spermatogenesis, supporting the tenet of conserved DNA packaging and likely functionality in human and mouse sperm.

Following the introduction of the sperm nucleus into the ooplasm, protamines are rapidly replaced by 

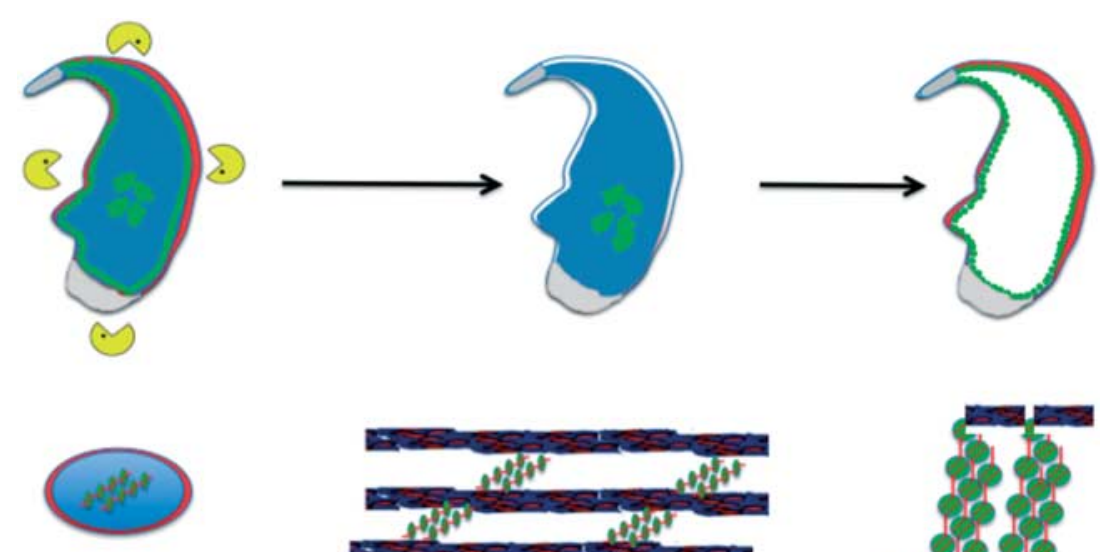

Undigested

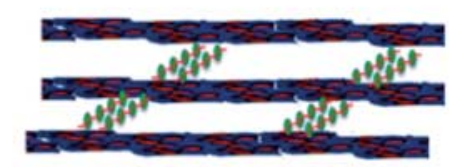

MNDI

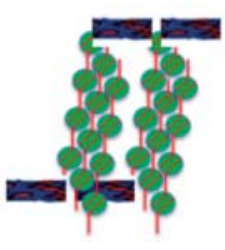

MNDS
Figure 5 Cartoon showing possible distribution of MNDS (red shading) and MNDI (blue shading) chromatin in mouse sperm nuclei (undigested). Nucleosomes are shown in green. Peripheral, nucleosomes-rich chromatin (MNDS) is released following limited digestion with micrococcal nuclease (Pacmen (yellow)). Undigested chromatin remains in the nucleus (MNDI). Below each cartoon is the suggested relationship between nucleosomes and protamines in undigested (nucleohistones minor component), MNDI (protamines dominate) and MNDS (nucleosomes dominate). maternal histones (McLay \& Clarke 2003). Our present and earlier data indicate that endonuclease-sensitive sperm chromatin is likely to be enriched in nucleosomes packaging distinctive gene families. Evidence for their transmission, to the zygote (van der Heijden et al. 2006, 2008), suggests that histone modifications in sperm chromatin may contribute epigenetically to the zygote. Although histone modifications in paternal chromatin could be one contributing route (Hammoud et al. 2009, Brykczynska et al. 2010), information 'embossed' into the differential packaging of sperm chromatin also offers potential non-Mendelian traits the chance to influence zygotic phenotype. Evidence for an epigenetic influence driving such variation has been presented for both human (Pembrey et al. 2006, Jirtle \& Skinner 2007) and animal inheritance (Chong et al. 2007). We speculate that the underlying framework for post-translational modifications including histone methylation is established by differential packaging of sperm chromatin, which the limited MNase digestion used in this and our related study (Arpanahi et al. 2009) both reveals and exploits.

\section{Materials and Methods}

\section{Sperm samples}

For chromatin fractionation, murine spermatozoa were obtained from the caudal end of dissected epididymides of outbred CD1 mice (Harlan, Shardlow, UK) and allowed to swim into HEPES-buffered synthetic oviduct fluid (HSOF; $21 \mathrm{mM}$ Hepes, $\mathrm{pH} 7.4,10 \mathrm{mM} \mathrm{NaCl}, 4 \mathrm{mM} \mathrm{NaHCO}$, $2.4 \mathrm{mM} \mathrm{CaCl}_{2}, 2 \mathrm{mM}$ GlutaMAX (Invitrogen), $0.8 \mathrm{mM} \mathrm{KCl}$, $0.6 \mathrm{mM}$ glucose, $0.47 \mathrm{mM}$ pyruvate, $0.2 \mathrm{mM} \mathrm{MgSO}_{4}, 0.1 \mathrm{mM}$ $\mathrm{KH}_{2} \mathrm{PO}_{4}$ and $3.56 \mathrm{mg} / \mathrm{ml}$ BSA (fraction $\mathrm{V}$ ), $0.04 \%$ sodium lactate syrup). Sperm suspensions were allowed to settle under gravity in a $1 \mathrm{~cm}$ diameter $\left(4 \mathrm{~cm}\right.$ depth) sterile tube at $30{ }^{\circ} \mathrm{C}$ for $60 \mathrm{~min}$ followed by careful aspiration of motile sperm from the upper levels. The aspirates were found to be essentially free of somatic cell contaminants by microscopic observation. Sperm were washed free of HSOF with PBS and processed for chromatin fractionation as described below. For immunocytochemistry, squash preparations of dissected epididymides were used. Human semen samples (following signed consent and approval by our local ethics review board) were obtained by masturbation into sterile receptacles. Following routine analysis, only normozoospermic samples (World Health Organisation 1999) were washed free of seminal plasma. Unless indicated, reagents were purchased from Sigma.

\section{MND and salt/restriction endonuclease digestion}

For digestion of mouse sperm chromatin, the method of Zalenskaya et al. (2000) was adapted with minor modifications. Sperm were washed in HSOF buffer and pellets were resuspended in $10 \mathrm{mM}$ Tris- $\mathrm{HCl}, \mathrm{pH}$ 8.0, containing $0.05 \%$ $(\mathrm{w} / \mathrm{v})$ phenylmethylsulphonylfluoride (PMSF) and $1 \%(\mathrm{w} / \mathrm{v})$ cetyltrimethylammonium bromide $(\mathrm{CTAB})$ to detach heads. Following centrifugation, pellets containing $\sim 10^{8}$ nuclei were resuspended in $\mathrm{Mg}^{+}{ }^{-}$and $\mathrm{Ca}^{2+}$-free $\mathrm{PBS}, 0.5 \%(\mathrm{v} / \mathrm{v})$ Triton $\mathrm{X}-100$ and incubated for $10 \mathrm{~min}$ at $4{ }^{\circ} \mathrm{C}$. Following centrifugation, the pellets were resuspended in $1 \mathrm{ml}$ PBS containing $0.5 \%$ PMSF and $10 \mathrm{mM}$ dithiothreitol (DTT) and incubated for 30 min at $37^{\circ} \mathrm{C} . \mathrm{CaCl}_{2}$ was added to a final concentration of $0.6 \mathrm{mM}$, and 5 units of MNase (Fermentas) were added. Digestion was stopped after $3 \mathrm{~min}$ of incubation by the addition of EDTA to $5 \mathrm{mM}$, and samples were gently agitated for $30 \mathrm{~min}$ at $37^{\circ} \mathrm{C}$ to allow digested chromatin to leach out from the nuclei. Following centrifugation at $5000 \mathrm{~g}$ for $10 \mathrm{~min}$, supernatants (MNDS) and pellets (MNDI) were processed for DNA extraction as follows: supernatants containing MNDS DNA were removed and treated with proteinase $\mathrm{K}(20 \mu \mathrm{g} / \mathrm{ml})$ and SDS $(0.5 \%(\mathrm{w} / \mathrm{v}))$ for $10 \mathrm{~h}$ at $55^{\circ} \mathrm{C}$. Prior to DNA extraction, RNAse A was added to the digest $(10 \mathrm{mg} / \mathrm{ml})$ and incubated for $1 \mathrm{~h}$ at $37^{\circ} \mathrm{C}$. DNA was then isolated by extraction in phenol chloroform (1:1) followed by ethanol precipitation. Tris-buffered saline containing proteinase $\mathrm{K}(200 \mathrm{mg} / \mathrm{ml}$; Bioline, London, UK) and $0.5 \%(\mathrm{w} / \mathrm{v})$ SDS was added to the pellets and incubated for $10 \mathrm{~h}$ at $55^{\circ} \mathrm{C}$. The MNDI DNA was isolated from the pellets as described above and precipitated DNA was dissolved in TE buffer and stored at $4{ }^{\circ} \mathrm{C}$. Mean DNA 
Table 3 Probes associated with promoter sequences returning $\log _{2} \mathrm{R}$ values $>0.5$ or $<-0.5$ were submitted to the DAVID Gene Ontology web server at http://david.abcc.ncifcrf.gov/ against a background list of the human genome. Only the top five bioprocess 'ALL' category following Benjamini correction (significantly enriched) is shown for the target categories and sorted by false discovery rate (FDR). Significantly enriched categories are shown in bold and based on both Benjamini $P$ value and the number of genes in each category.

\begin{tabular}{|c|c|c|c|c|c|c|c|}
\hline Term & Count & $\begin{array}{l}\text { Percentage } \\
\quad(\%)\end{array}$ & $P$ value & $\begin{array}{c}\text { Fold } \\
\text { enrichment }\end{array}$ & Bonferroni & Benjamini & FDR \\
\hline \multicolumn{8}{|l|}{ C-MNDS } \\
\hline GO:0030154 cell differentiation & 176 & 13.17365269 & $2.06 \times 10^{-7}$ & 1.45 & $6.81 \times 10^{-4}$ & $6.81 \times 10^{-4}$ & $3.74 \times 10^{-4}$ \\
\hline $\begin{array}{l}\text { GO:0048869 cellular developmental } \\
\text { process }\end{array}$ & 179 & 13.39820359 & $8.72 \times 10^{-7}$ & 1.41 & $2.89 \times 10^{-3}$ & $1.44 \times 10^{-3}$ & $1.59 \times 10^{-3}$ \\
\hline GO:0009605 response to external stimulus & 83 & 6.21257485 & $3.54 \times 10^{-6}$ & 1.67 & $1.17 \times 10^{-2}$ & $3.91 \times 10^{-3}$ & $6.45 \times 10^{-3}$ \\
\hline GO:0030182 neuron differentiation & 56 & 4.191616766 & $1.92 \times 10^{-5}$ & 1.81 & $6.17 \times 10^{-2}$ & $1.58 \times 10^{-2}$ & $3.50 \times 10^{-2}$ \\
\hline GO:0032502 $\sim$ developmental process & 267 & 19.98502994 & $1.96 \times 10^{-5}$ & 1.26 & $6.29 \times 10^{-2}$ & $1.29 \times 10^{-2}$ & $3.56 \times 10^{-2}$ \\
\hline \multicolumn{8}{|l|}{$\mathrm{C}-\mathrm{MNDI}$} \\
\hline $\begin{array}{l}\text { GO:0007606 sensory perception of } \\
\text { chemical stimulus }\end{array}$ & 63 & 16.19537275 & $3.79 \times 10^{-10}$ & 2.33 & $6.08 \times 10^{-7}$ & $6.08 \times 10^{-7}$ & $6.35 \times 10^{-7}$ \\
\hline $\begin{array}{l}\text { GO:0007186 } \sim \text { G-protein coupled receptor } \\
\text { protein signalling pathway }\end{array}$ & 84 & 21.59383033 & $7.04 \times 10^{-10}$ & 1.97 & $1.13 \times 10^{-6}$ & $5.65 \times 10^{-7}$ & $1.18 \times 10^{-6}$ \\
\hline GO:0007608 sensory perception of smell & 57 & 14.6529563 & $1.18 \times 10^{-8}$ & 2.25 & $1.89 \times 10^{-5}$ & $6.31 \times 10^{-6}$ & $1.98 \times 10^{-5}$ \\
\hline $\begin{array}{l}\text { GO:0007166 cell surface receptor linked } \\
\text { signal transduction }\end{array}$ & 98 & 25.19280206 & $1.58 \times 10^{-8}$ & 1.73 & $2.53 \times 10^{-5}$ & $6.33 \times 10^{-6}$ & $2.64 \times 10^{-5}$ \\
\hline GO:0007600 sensory perception & 64 & 16.45244216 & $7.76 \times 10^{-8}$ & 2.01 & $1.24 \times 10^{-4}$ & $2.49 \times 10^{-5}$ & $1.30 \times 10^{-4}$ \\
\hline \multicolumn{8}{|l|}{$C+$ MNDS } \\
\hline GO:0006811 ion transport & 93 & 8.707865169 & $9.57 \times 10^{-11}$ & 2.01 & $3.10 \times 10^{-7}$ & $3.10 \times 10^{-7}$ & $1.74 \times 10^{-7}$ \\
\hline GO:0009987 cellular process & 687 & 64.3258427 & $1.44 \times 10^{-10}$ & 1.15 & $4.65 \times 10^{-7}$ & $2.32 \times 10^{-7}$ & $2.61 \times 10^{-7}$ \\
\hline $\begin{array}{l}\text { GO:0010646 regulation of cell } \\
\text { communication }\end{array}$ & 96 & 8.988764045 & $6.20 \times 10^{-10}$ & 1.92 & $2.01 \times 10^{-6}$ & $6.69 \times 10^{-7}$ & $1.13 \times 10^{-6}$ \\
\hline GO:0006812 cation transport & 70 & 6.554307116 & $5.45 \times 10^{-9}$ & 2.10 & $1.76 \times 10^{-5}$ & $4.41 \times 10^{-6}$ & $9.89 \times 10^{-6}$ \\
\hline GO:0006810 transport & 218 & 20.41198502 & $6.25 \times 10^{-9}$ & 1.44 & $2.02 \times 10^{-5}$ & $4.04 \times 10^{-6}$ & $1.13 \times 10^{-5}$ \\
\hline \multicolumn{8}{|l|}{$\mathrm{C}+\mathrm{MNDI}$} \\
\hline $\begin{array}{l}\text { GO:0007275 multicellular organismal } \\
\text { development }\end{array}$ & 49 & 27.52808989 & $1.82 \times 10^{-5}$ & 1.82 & $2.22 \times 10^{-2}$ & $2.22 \times 10^{-2}$ & $2.95 \times 10^{-2}$ \\
\hline $\begin{array}{l}\text { GO:0032502 developmental } \\
\text { process }\end{array}$ & 50 & 28.08988764 & $7.91 \times 10^{-5}$ & 1.71 & $9.28 \times 10^{-2}$ & $4.75 \times 10^{-2}$ & $1.28 \times 10^{-1}$ \\
\hline GO:0048731 system development & 38 & 21.34831461 & $5.39 \times 10^{-4}$ & 1.75 & $4.85 \times 10^{-1}$ & $1.99 \times 10^{-1}$ & $8.71 \times 10^{-1}$ \\
\hline GO:0007399 nervous system development & 21 & 11.79775281 & $7.08 \times 10^{-4}$ & 2.30 & $5.82 \times 10^{-1}$ & $1.96 \times 10^{-1}$ & 1.14 \\
\hline $\begin{array}{l}\text { GO:0048869 cellular developmental } \\
\text { process }\end{array}$ & 32 & 17.97752809 & $9.19 \times 10^{-4}$ & 1.83 & $6.78 \times 10^{-1}$ & $2.03 \times 10^{-1}$ & 1.48 \\
\hline \multicolumn{8}{|l|}{$C-5 m C+M N D S$} \\
\hline GO:0009605 response to external stimulus & 56 & 8.104196816 & $2.56 \times 10^{-8}$ & 2.25 & $6.22 \times 10^{-5}$ & $6.22 \times 10^{-5}$ & $4.51 \times 10^{-5}$ \\
\hline GO:0050896 response to stimulus & 144 & 20.83936324 & $9.10 \times 10^{-8}$ & 1.52 & $2.21 \times 10^{-4}$ & $1.10 \times 10^{-4}$ & $1.60 \times 10^{-4}$ \\
\hline GO:0009611 response to wounding & 33 & 4.77568741 & $5.54 \times 10^{-6}$ & 2.44 & $1.34 \times 10^{-2}$ & $4.47 \times 10^{-3}$ & $9.74 \times 10^{-3}$ \\
\hline GO:0006954 inflammatory response & 24 & 3.473227207 & $2.31 \times 10^{-5}$ & 2.74 & $5.44 \times 10^{-2}$ & $1.39 \times 10^{-2}$ & $4.05 \times 10^{-2}$ \\
\hline GO:0006955 immune response & 38 & 5.499276411 & $3.99 \times 10^{-5}$ & 2.07 & $9.22 \times 10^{-2}$ & $1.92 \times 10^{-2}$ & $7.00 \times 10^{-2}$ \\
\hline \multicolumn{8}{|l|}{$\mathrm{C}-5 \mathrm{mC}+\mathrm{MNDI}$} \\
\hline $\begin{array}{l}\text { GO:0007186 G-protein coupled receptor } \\
\text { protein signalling pathway }\end{array}$ & 34 & 26.77165354 & $9.50 \times 10^{-7}$ & 2.43 & $7.14 \times 10^{-4}$ & $7.14 \times 10^{-4}$ & $1.45 \times 10^{-3}$ \\
\hline $\begin{array}{l}\text { GO:0007606 sensory perception of } \\
\text { chemical stimulus }\end{array}$ & 26 & 20.47244094 & $1.32 \times 10^{-6}$ & 2.93 & $9.93 \times 10^{-4}$ & $4.97 \times 10^{-4}$ & $2.01 \times 10^{-3}$ \\
\hline GO:0007608 $\sim$ sensory perception of smell & 23 & 18.11023622 & $1.77 \times 10^{-5}$ & 2.76 & $1.32 \times 10^{-2}$ & $4.43 \times 10^{-3}$ & $2.70 \times 10^{-2}$ \\
\hline GO:0007600 $\sim$ sensory perception & 26 & 20.47244094 & $2.32 \times 10^{-5}$ & 2.49 & $1.73 \times 10^{-2}$ & $4.35 \times 10^{-3}$ & $3.54 \times 10^{-2}$ \\
\hline $\begin{array}{l}\text { GO:0007166 cell surface receptor linked } \\
\text { signal transduction }\end{array}$ & 37 & 29.13385827 & $2.63 \times 10^{-5}$ & 1.99 & $1.96 \times 10^{-2}$ & $3.94 \times 10^{-3}$ & $4.00 \times 10^{-2}$ \\
\hline \multicolumn{8}{|l|}{$C-5 \mathrm{mC}-\mathrm{MNDS}$} \\
\hline GO:0009987 cellular process & 397 & 65.29605263 & $2.22 \times 10^{-9}$ & 1.18 & $5.46 \times 10^{-6}$ & $5.46 \times 10^{-6}$ & $3.91 \times 10^{-6}$ \\
\hline GO:0030182 neuron differentiation & 38 & 6.25 & $1.56 \times 10^{-7}$ & 2.62 & $3.83 \times 10^{-4}$ & $1.91 \times 10^{-4}$ & $2.74 \times 10^{-4}$ \\
\hline $\begin{array}{l}\text { GO:0007417 central nervous system } \\
\text { development }\end{array}$ & 35 & 5.756578947 & $5.84 \times 10^{-7}$ & 2.61 & $1.43 \times 10^{-3}$ & $4.78 \times 10^{-4}$ & $1.03 \times 10^{-3}$ \\
\hline GO:0007420 brain development & 29 & 4.769736842 & $2.07 \times 10^{-6}$ & 2.77 & $5.08 \times 10^{-3}$ & $1.27 \times 10^{-3}$ & $3.65 \times 10^{-3}$ \\
\hline GO:0007399 nervous system development & 59 & 9.703947368 & $2.53 \times 10^{-6}$ & 1.90 & $6.19 \times 10^{-3}$ & $1.24 \times 10^{-3}$ & $4.45 \times 10^{-3}$ \\
\hline \multicolumn{8}{|l|}{$\mathrm{C}-5 \mathrm{mC}-\mathrm{MNDI}$} \\
\hline $\begin{array}{l}\text { GO:0032501 multicellular organismal } \\
\text { process }\end{array}$ & 91 & 36.99186992 & $1.14 \times 10^{-5}$ & 1.48 & $1.50 \times 10^{-2}$ & $1.50 \times 10^{-2}$ & $1.87 \times 10^{-2}$ \\
\hline $\begin{array}{l}\text { GO:0007606 sensory perception of } \\
\text { chemical stimulus }\end{array}$ & 36 & 14.63414634 & $2.54 \times 10^{-5}$ & 2.13 & $3.32 \times 10^{-2}$ & $1.67 \times 10^{-2}$ & $4.15 \times 10^{-2}$ \\
\hline $\begin{array}{l}\text { GO:0007166 cell surface receptor linked } \\
\text { signal transduction }\end{array}$ & 58 & 23.57723577 & $9.23 \times 10^{-5}$ & 1.64 & $1.16 \times 10^{-1}$ & $4.01 \times 10^{-2}$ & $1.51 \times 10^{-1}$ \\
\hline GO:0007608 $\sim$ sensory perception of smell & 33 & 13.41463415 & $9.47 \times 10^{-5}$ & 2.08 & $1.18 \times 10^{-1}$ & $3.10 \times 10^{-2}$ & $1.55 \times 10^{-1}$ \\
\hline GO:0003008 system process & 46 & 18.69918699 & $1.02 \times 10^{-4}$ & 1.78 & $1.27 \times 10^{-1}$ & $2.68 \times 10^{-2}$ & $1.67 \times 10^{-1}$ \\
\hline \multicolumn{8}{|l|}{$C+5 m C+M N D S$} \\
\hline GO:0006811 ion transport & 61 & 10.40955631 & $3.26 \times 10^{-10}$ & 2.41 & $8.36 \times 10^{-7}$ & $8.36 \times 10^{-7}$ & $5.77 \times 10^{-7}$ \\
\hline GO:0006812 cation transport & 47 & 8.020477816 & $7.44 \times 10^{-9}$ & 2.57 & $1.90 \times 10^{-5}$ & $9.52 \times 10^{-6}$ & $1.32 \times 10^{-5}$ \\
\hline
\end{tabular}


Table 3 Continued.

\begin{tabular}{|c|c|c|c|c|c|c|c|}
\hline Term & Count & $\begin{array}{l}\text { Percentage } \\
\quad(\%)\end{array}$ & $P$ value & $\begin{array}{c}\text { Fold } \\
\text { enrichment }\end{array}$ & Bonferroni & Benjamini & FDR \\
\hline GO:0051234 establishment of localisation & 130 & 22.18430034 & $1.10 \times 10^{-7}$ & 1.55 & $2.81 \times 10^{-4}$ & $9.38 \times 10^{-5}$ & $1.94 \times 10^{-4}$ \\
\hline GO:0006810 transport & 129 & 22.01365188 & $1.32 \times 10^{-7}$ & 1.55 & $3.38 \times 10^{-4}$ & $8.46 \times 10^{-5}$ & $2.34 \times 10^{-4}$ \\
\hline $\begin{array}{l}\text { GO:0065008 regulation of biological } \\
\text { quality }\end{array}$ & 73 & 12.45733788 & $5.44 \times 10^{-7}$ & 1.83 & $1.39 \times 10^{-3}$ & $2.79 \times 10^{-4}$ & $9.63 \times 10^{-4}$ \\
\hline \multicolumn{8}{|l|}{$\mathrm{C}+5 \mathrm{mC}+\mathrm{MNDI}$} \\
\hline GO:0007155 cell adhesion & 9 & 13.84615385 & $6.94 \times 10^{-4}$ & 4.47 & $3.60 \times 10^{-1}$ & $3.60 \times 10^{-1}$ & 1.03 \\
\hline GO:0022610 biological adhesion & 9 & 13.84615385 & $7.02 \times 10^{-4}$ & 4.46 & $3.63 \times 10^{-1}$ & $2.02 \times 10^{-1}$ & 1.04 \\
\hline GO:0007154 cell communication & 8 & 12.30769231 & $9.96 \times 10^{-4}$ & 4.90 & $4.73 \times 10^{-1}$ & $1.92 \times 10^{-1}$ & 1.48 \\
\hline $\begin{array}{l}\text { GO:0019226 transmission of nerve } \\
\text { impulse }\end{array}$ & 6 & 9.230769231 & $1.15 \times 10^{-3}$ & 7.40 & $5.22 \times 10^{-1}$ & $1.69 \times 10^{-1}$ & 1.70 \\
\hline $\begin{array}{l}\text { GO:0007275 multicellular organismal } \\
\text { development }\end{array}$ & 19 & 29.23076923 & $1.58 \times 10^{-3}$ & 2.10 & $6.38 \times 10^{-1}$ & $1.84 \times 10^{-1}$ & 2.33 \\
\hline \multicolumn{8}{|l|}{$\mathrm{C}+5 \mathrm{mC}-\mathrm{MNDS}$} \\
\hline GO:0009987 cellular process & 318 & 69.58424508 & $8.02 \times 10^{-11}$ & 1.22 & $1.72 \times 10^{-7}$ & $1.72 \times 10^{-7}$ & $1.39 \times 10^{-7}$ \\
\hline $\begin{array}{l}\text { GO:0010646 regulation of cell } \\
\text { communication }\end{array}$ & 44 & 9.628008753 & $1.23 \times 10^{-5}$ & 2.03 & $2.61 \times 10^{-2}$ & $1.31 \times 10^{-2}$ & $2.14 \times 10^{-2}$ \\
\hline $\begin{array}{l}\text { GO:0051969 regulation of transmission of } \\
\text { nerve impulse }\end{array}$ & 13 & 2.84463895 & $4.42 \times 10^{-5}$ & 4.33 & $9.05 \times 10^{-2}$ & $3.11 \times 10^{-2}$ & $7.65 \times 10^{-2}$ \\
\hline GO:0044237 cellular metabolic process & 203 & 44.42013129 & $5.88 \times 10^{-5}$ & 1.24 & $1.19 \times 10^{-1}$ & $3.11 \times 10^{-2}$ & $1.02 \times 10^{-1}$ \\
\hline $\begin{array}{l}\text { GO:0031644 regulation of neurological } \\
\text { system process }\end{array}$ & 13 & 2.84463895 & $7.57 \times 10^{-5}$ & 4.10 & $1.50 \times 10^{-1}$ & $3.20 \times 10^{-2}$ & $1.31 \times 10^{-1}$ \\
\hline \multicolumn{8}{|l|}{$\mathrm{C}+5 \mathrm{mC}-\mathrm{MNDI}$} \\
\hline $\begin{array}{l}\text { GO:0000904 cell morphogenesis involved } \\
\text { in differentiation }\end{array}$ & 6 & 5.769230769 & $1.21 \times 10^{-2}$ & 4.33 & 1.00 & 1.00 & $1.73 \times 10^{1}$ \\
\hline GO:0006281 DNA repair & 6 & 5.769230769 & $1.46 \times 10^{-2}$ & 4.13 & 1.00 & $9.98 \times 10^{-1}$ & $2.04 \times 10^{1}$ \\
\hline GO:0000902 cell morphogenesis & 7 & 6.730769231 & $1.50 \times 10^{-2}$ & 3.46 & 1.00 & $9.88 \times 10^{-1}$ & $2.10 \times 10^{1}$ \\
\hline $\begin{array}{l}\text { GO:0007275 multicellular organismal } \\
\text { development }\end{array}$ & 26 & 25 & $1.58 \times 10^{-2}$ & 1.58 & 1.00 & $9.69 \times 10^{-1}$ & $2.19 \times 10^{1}$ \\
\hline $\begin{array}{l}\text { GO:0016043 cellular component } \\
\text { organisation }\end{array}$ & 21 & 20.19230769 & $1.69 \times 10^{-2}$ & 1.70 & 1.00 & $9.50 \times 10^{-1}$ & $2.33 \times 10^{1}$ \\
\hline
\end{tabular}

yields in the recovered fractions from several independent digestion reactions averaged $1.36 \mu \mathrm{g}$ for MNDS and $343 \mu \mathrm{g}$ for MNDI. MNDS DNA, therefore, contributes $\sim 0.6 \%(\mathrm{w} / \mathrm{w})$ of the total DNA recovered from digested mouse sperm chromatin.

Human spermatozoa were processed as described previously (Arpanahi et al. 2009). Briefly, ejaculate spermatozoa were washed free of seminal plasma by diluting the semen 1:1 with HEPES buffered HSOF and centrifuging for $10 \mathrm{~min}$ at $500 \mathrm{~g}$. Pellets were resuspended in HSOF and centrifuged as before. Pellets were resuspended in $100 \mathrm{mM} \mathrm{NaCl}, 10 \mathrm{mM}$ Tris- $\mathrm{HCl}$, pH 8.0, $1 \mathrm{mM}$ EDTA containing $0.2 \mathrm{mM}$ PMSF and re-pelleted to remove HSOF. Pellets were subsequently processed by sequential extraction in $10 \%(\mathrm{w} / \mathrm{v})$ mixed CTAB (alklytrimethylammonium bromide); sequential incubation in $1 \% \mathrm{w} / \mathrm{v} \mathrm{CTAB}$ in $10 \mathrm{mM}$ Tris- $\mathrm{HCl}, \mathrm{pH} 8.0$, containing $0.05 \%$ $\mathrm{w} / \mathrm{v}$ digitonin; Tris-buffered saline (TBS) containing $0.05 \% \mathrm{w} / \mathrm{v}$ digitonin; $10 \mathrm{mM}$ Tris- $\mathrm{HCl}, \mathrm{pH}$ 8.0, containing $1 \mathrm{mM}$ EDTA, $0.05 \% \mathrm{w} / \mathrm{v}$ digitonin, EDTA-free protease inhibitor cocktail (Roche) and finally extraction in $0.65 \mathrm{M} \mathrm{NaCl}$. The pellets containing $\sim 5 \times 10^{8}$ nuclei were then resuspended in BamHI buffer and digested with $2000 \mathrm{U}$ each of EcoRI and BamHI (Invitrogen) for $90 \mathrm{~min}$ at $37^{\circ} \mathrm{C}$ with gentle agitation, allowing digested DNA to leach out of the nuclei. Following centrifugation, supernatants containing salt/restriction endonuclease digestion solubilised DNA (SRDS) were removed and treated with proteinase $\mathrm{K}(200 \mu \mathrm{g} / \mathrm{ml})$ and SDS $(0.5 \% \mathrm{w} / \mathrm{v})$ for $10 \mathrm{~h}$ at $55^{\circ} \mathrm{C}$. Prior to DNA extraction, RNAse $\mathrm{A}$ was added to the digest $(10 \mathrm{mg} / \mathrm{ml})$ and incubated for $1 \mathrm{~h}$ at $37^{\circ} \mathrm{C}$. DNA was then isolated by extraction in phenol chloroform $(1: 1)$ followed by ethanol precipitation. Precipitated DNA was dissolved in TE buffer and stored at $4{ }^{\circ} \mathrm{C}$. Residual pellets (SRDI) were re-suspended in BamHI buffer containing 0.05\% digitonin and digested with $\sim 150$ units each of BamHI and EcoRI for $90 \mathrm{~min}$ at $37^{\circ} \mathrm{C}$ with gentle agitation. Suspensions were centrifuged at $3000 \mathrm{~g}$ for $5 \mathrm{~min}$ and the supernatants were removed. TBS containing proteinase $\mathrm{K}(200 \mu \mathrm{g} / \mathrm{ml}$; Bioline), $0.5 \% \mathrm{w} / \mathrm{v}$ SDS was added to this suspension and incubated for $10 \mathrm{~h}$ at $55^{\circ} \mathrm{C}$. DNA was isolated from the pellets as described above. Unless indicated, reagents were purchased from Sigma.

Mean DNA yields in the recovered fractions from several independent digestion reactions were $64 \mu \mathrm{g}$ for SRDS and $475 \mu \mathrm{g}$ for SRDI. SRDS DNA, therefore, contributes $\sim 12 \%$ of the total DNA recovered from digested human sperm chromatin.

\section{CGH profiling (experimental)}

Because of the small quantities of MNDS DNA obtained from mouse sperm chromatin, 20 ng each of MNDS and MNDI DNA were amplified by WGA using the GenomiPhi DNA Amplification kit (GE Healthcare, Hatfield, UK). Amplified DNA was digested with $10 \mathrm{U}$ Rsal and Alul (New England Biolabs, Hitchin, UK) for $2 \mathrm{~h}$ at $37^{\circ} \mathrm{C}$. After phenol/chloroform extraction and ethanol precipitation, $1 \mu \mathrm{g}$ DNA was labelled with either cyanine 3 (Cy3) or Cy5 fluorescent dyes using $20 \mu \mathrm{l}$ $2.5 \times$ random primer mix, $40 \cup$ exo-Klenow enzyme (Bioprime DNA Labelling kit, Invitrogen), $1 \mu$ l Cy3- or Cy5-dCTP (GE Healthcare), $5 \mu$ l low dCTP-dNTP mix ( $5 \mathrm{mM}$ dGTP, $5 \mathrm{mM}$ dTTP, $5 \mathrm{mM}$ dATP and $2 \mathrm{mM}$ dCTP). The labelling reaction was carried out for $30 \mathrm{~min}$ at $16{ }^{\circ} \mathrm{C}$ and for $16 \mathrm{~h}$ at $37^{\circ} \mathrm{C}$ and then 
stopped by adding $5 \mu$ Stop buffer (Bioprime DNA Labelling kit, Invitrogen). The labelled DNA was purified on G-50 columns (GE Healthcare) and kept in the dark at $-20{ }^{\circ} \mathrm{C}$ until further use. Identical labelling reactions were undertaken on human sperm SRDS and SRDI fractions but without prior amplification.

CGH profiling was carried out according to the array manufacturer's (Agilent 244A) instructions (Agilent, Wokingham, UK). For hybridisation, equal quantities of labelled DNA (500 or $1000 \mathrm{ng})$ were mixed with Cot-1 DNA $(1 \mathrm{mg} / \mathrm{ml})$ and incubated for $3 \mathrm{~min}$ at $95^{\circ} \mathrm{C}$ and then reincubated for $30 \mathrm{~min}$ at $37^{\circ} \mathrm{C}$. The target DNAs $(490 \mu \mathrm{l})$ were applied to arrays, sealed and incubated for $40 \mathrm{~h}$ at $65^{\circ} \mathrm{C}$ with constant rotation. Arrays were washed according to the manufacturer's instructions using Agilent buffers, dried and scanned on an Agilent BA laser scanner. Data were recovered using Agilent's Feature Extraction Software and visualised using their CGH Analytics Software. All data were transformed using a rank consistency filter method with linear normalisation during feature extraction.

\section{CGH profiling (in silico)}

In addition to the experimental work described above, predicted profiles likely to be obtained by comparisons between digested and undigested mouse sperm targets were modelled in silico by weighting processed peak intensities to the experimentally derived DNA yields from digested mouse sperm chromatin (0.6\% MNDS and $99.4 \% \mathrm{MNDI}) . \mathrm{Log}_{2}$ ratios were then obtained as follows: (MNDS/MNDI), (MNDS/ $(\mathrm{MNDI}+\mathrm{MNDS}))$ and $((\mathrm{MNDI} /(\mathrm{MNDI}+\mathrm{MNDS}))$. Smoothed spline plots of the results were generated in $\mathrm{R}$ version 2.12.1 (http://www.r-project.org/).

\section{Fluorescence in situ hybridisation}

Murine spermatozoa were washed twice in PBS at $600 \mathrm{~g}$ for $5 \mathrm{~min}$. Cells were resuspended in PBS at an approximate concentration of $10^{6}$ cells $/ \mathrm{ml}$. Suspensions $(5 \mu \mathrm{l})$ were spread onto ethanol pre-cleaned glass slides and allowed to air-dry. Sperm were decondensed at room temperature in $0.1 \mathrm{M}$ Tris-Cl, pH 7.8, $10 \mathrm{mM}$ DTT, washed briefly in $0.1 \mathrm{M}$ Tris-Cl, $\mathrm{pH} 7.8$, and allowed to air-dry at room temperature. Sperm DNA was denatured for $5 \mathrm{~min}$ at $75^{\circ} \mathrm{C}$ in $70 \%$ formamide, $2 \times$ sodium chloride-sodium citrate buffer (SSC) and cells were fixed in an ethanol series 70/85/100\% for 2 min each and allowed to air-dry.

For probe labelling, 500 ng of WGA-amplified MNDS and MNDI DNAs were nick-translated with biotin or digoxigenin. Labelling reactions were prepared according to the manufacturer's instructions (BioPrime DNA Labelling System, Invitrogen). The DNA was denatured for $5 \mathrm{~min}$ at $100{ }^{\circ} \mathrm{C}$, and after rapid cooling on ice, $20 \mathrm{U}$ Klenow fragment (BioPrime DNA Labelling System, Invitrogen) were added. The reaction mixes were incubated overnight at $37^{\circ} \mathrm{C}$ and stopped by adding $2 \mu \mathrm{l}$ Stop buffer (BioPrime DNA Labelling System, Invitrogen). Labelled DNA fractions were purified from unincorporated label on G-50 columns (GE Healthcare). For hybridisation, $1 \mu \mathrm{g}$ mouse Cot-1 DNA (Invitrogen) and $10 \mu \mathrm{g}$ salmon sperm DNA (Invitrogen) were added to $2 \mu \mathrm{l}(\approx 150 \mathrm{ng}$ ) labelled probe.
After glycogen/ethanol precipitation, pellets were resuspended in $3 \mu \mathrm{l}$ distilled water followed by the addition of $7 \mu \mathrm{l}$ master $\operatorname{mix}(78.6 \%$ formamide, $14.3 \%$ dextran sulphate, $1.43 \times$ SSC buffer). The DNA was then denatured for $10 \mathrm{~min}$ at $75^{\circ} \mathrm{C}$ and pre-annealed for $30 \mathrm{~min}$ at $37^{\circ} \mathrm{C}$. Hybridisation mixes were carefully applied to slides, cover slips were added sealed in place and slides were incubated in a moistened box at $37^{\circ} \mathrm{C}$ for $48 \mathrm{~h}$. Cover slips were then removed in $2 \times$ SSC buffer and slides, washed once for $5 \mathrm{~min}$ in $0.1 \times \mathrm{SSC}$ at $45^{\circ} \mathrm{C}$ and twice for $5 \mathrm{~min}$ in $2 \times \mathrm{SSC}, 10 \%$ phosphate-nonidet (PN) buffer $\left(0.1 \mathrm{M} \mathrm{Na}_{2} \mathrm{HPO}_{4} / \mathrm{NaH}_{2} \mathrm{PO}_{4} \mathrm{pH} 8,0.05 \%\right.$ Nonidet P-40) at room temperature.

For visualisation, samples were blocked with $200 \mu \mathrm{l}$ blocking solution (5\% dry milk powder in PN buffer) for $30 \mathrm{~min}$ at room temperature and incubated in $200 \mu \mathrm{l} 1 / 100$ TRITC conjugated avidin (Invitrogen) dilution or a $1 / 25$ fluorescein conjugated anti-digoxigenin Fab-specific antibody (Roche) dilution in blocking solution for $2 \mathrm{~h}$ at $37^{\circ} \mathrm{C}$. Slides were then washed twice for $10 \mathrm{~min}$ at room temperature in $2 \times$ SSC and mounted in DAPI containing medium (Vectashield; Vector Laboratories Ltd, Peterborough, UK). Cells were observed under Leitz DMRB microscope (Leica, Milton Keynes, UK) coupled to Sen Sys camera (Photometrics, Tucson, AZ, USA) with a final $\times 1000$ magnification and pictures were integrated using Vysis SpectraVysion Software (Applied Imaging International, Newcastle upon Tyne, UK).

\section{Immunocytochemistry}

Squash preparations of mouse epididymal extracts were decondensed as above and then fixed with $4 \%$ paraformaldehyde for $10 \mathrm{~min}$ prior to storage at $4{ }^{\circ} \mathrm{C}$ until use. For antibody labelling, the Abcam protocol was used with some modifications. Sperm samples were suspended in PBS for $1 \mathrm{~min}$, then permeabilised with $0.25 \%$ Triton X-100 for 5 min after which samples were washed $3 \times$ with PBS for 5 min each. Slides were blocked as above and primary antibody (anti-core histone) was applied at 1:50 dilution in PBS containing 1\% dried milk powder overnight at $4{ }^{\circ} \mathrm{C}$. Slides were washed $\times 4$ in BPS for 5 min each followed by incubation in the secondary FITCconjugated antibody for $1 \mathrm{~h}$ at room temperature. Slides were then washed as before prior to adding $30 \mu \mathrm{l}$ of $0.5 \mu \mathrm{g} / \mathrm{ml} \mathrm{4,6-}$ DAPI for $5 \mathrm{~min}$. Cells were observed under a Leitz DMRB microscope (Leica) coupled to SenSys camera (Photometrics) as above.

\section{Statistical analysis and bioinformatics}

The linear regression, correlation and $\chi^{2}$ analyses of $\mathrm{CGH}$ data were written in $R$ 2.12.1. Graphic output was obtained using both $\mathrm{R}$ and Adobe CS3 Software. Probe coordinates from the Agilent $244 \mathrm{~K} \mathrm{CGH}$ data sets that overlapped with promoter sequences obtained from the NimbleGen twin promoter array data set and the CTCF coordinates for mouse (Chen et al. 2008) and human (http://hgdownload-test.cse. ucsc.edu/goldenPath/hg18/encodeDCC.00/wgEncodeBroad ChipSeq/wgEncodeBroadChipSeqPeaksH1 hescCtcf.broad Peak.gz) ES cell lines were collated using scripts available at Galaxy (http://main.g2.bx.psu.edu/). Galaxy scripts were 
also used to ensure that each $\mathrm{CGH}$ probe was counted only once in any analysis. Ontology analysis was carried out using the DAVID 6.7 Suite of Bioinformatic Tools (Huang et al. 2009; http://david.abcc.ncifcrf.gov/).

The MIAME compliant microarray data from this study have been submitted to NCBI Gene Expression Omnibus (GEO) (http://www.ncbi.nlm.nih.gov/geo/) under accession number GSE15941.

Supplementary information can be found at the authors' website (http://www.personal.leeds.ac.uk/ patdm/index_ copy.htm).

\section{Declaration of interest}

The authors declare that there is no conflict of interest that could be perceived as prejudicing the impartiality of the research reported.

\section{Funding}

The authors gratefully acknowledge the financial support of the BBSRC and a Marie Curie Training scholarship awarded to $M$ Saida.

\section{References}

Allen MJ, Bradbury EM \& Balhorn R 1996 The chromatin structure of wellspread demembranated human sperm nuclei revealed by atomic force microscopy. Scanning Microscopy 10 989-994.

Arpanahi A, Brinkworth M, Iles D, Krawetz SA, Paradowska A, Platts AE, Saida M, Steger K, Tedder P \& Miller D 2009 Endonuclease-sensitive regions of human spermatozoal chromatin are highly enriched in promoter and CTCF binding sequences. Genome Research 19 1338-1349. (doi:10. 1101/gr.094953.109)

Balhorn R 2007 The protamine family of sperm nuclear proteins. Genome Biology 8 227. (doi:10.1186/gb-2007-8-9-227)

Braun RE 2001 Packaging paternal chromosomes with protamine. Nature Genetics 28 10-12. (doi:10.1038/ng0501-10)

Breitbart H 2003 Signaling pathways in sperm capacitation and acrosome reaction. Cellular and Molecular Biology 49 321-327.

Brewer LR, Corzett M \& Balhorn R 1999 Protamine-induced condensation and decondensation of the same DNA molecule. Science 286 120-123. (doi:10.1126/science.286.5437.120)

Brewer L, Corzett M, Lau EY \& Balhorn R 2003 Dynamics of protamine 1 binding to single DNA molecules. Journal of Biological Chemistry 278 42403-42408. (doi:10.1074/jbc.M303610200)

Brykczynska U, Hisano M, Erkek S, Ramos L, Oakeley EJ, Roloff TC, Beisel C, Schubeler D, Stadler MB \& Peters AH 2010 Repressive and active histone methylation mark distinct promoters in human and mouse spermatozoa. Nature Structural \& Molecular Biology 17 679-687. (doi:10.1038/nsmb.1821)

Chen HL, Li T, Qiu XW, Wu J, Ling JQ, Sun ZH, Wang W, Chen W, Hou A, Vu TH et al. 2006 Correction of aberrant imprinting of IGF2 in human tumors by nuclear transfer-induced epigenetic reprogramming. EMBO Journal 25 5329-5338. (doi:10.1038/sj.emboj.7601399)

Chen X, Xu H, Yuan P, Fang F, Huss M, Vega VB, Wong E, Orlov YL, Zhang W, Jiang J et al. 2008 Integration of external signaling pathways with the core transcriptional network in embryonic stem cells. Cell 133 1106-1117. (doi:10.1016/j.cell.2008.04.043)

Chong S, Vickaryous N, Ashe A, Zamudio N, Youngson N, Hemley S, Stopka T, Skoultchi A, Matthews J, Scott HS et al. 2007 Modifiers of epigenetic reprogramming show paternal effects in the mouse. Nature Genetics 39 614-622. (doi:10.1038/ng2031)

Collas P \& Poccia D 1998 Remodeling the sperm nucleus into a male pronucleus at fertilization. Theriogenology 49 67-81. (doi:10.1016/ S0093-691X(97)00403-2)
Crasto C, Marenco L, Miller P \& Shepherd G 2002 Olfactory receptor database: a metadata-driven automated population from sources of gene and protein sequences. Nucleic Acids Research 30 354-360. (doi:10. 1093/nar/30.1.354)

Farthing CR, Ficz G, Ng RK, Chan CF, Andrews S, Dean W, Hemberger M \& Reik W 2008 Global mapping of DNA methylation in mouse promoters reveals epigenetic reprogramming of pluripotency genes. PLoS Genetics 4 e1000116. (doi:10.1371/journal.pgen.1000116)

Gardiner-Garden M, Ballesteros M, Gordon M \& Tam PP 1998 Histoneand protamine-DNA association: conservation of different patterns within the beta-globin domain in human sperm. Molecular and Cellular Biology 18 3350-3356.

Gatewood JM, Cook GR, Balhorn R, Bradbury EM \& Schmid CW 1987 Sequence-specific packaging of DNA in human sperm chromatin. Science 236 962-964. (doi:10.1126/science.3576213)

Gatewood JM, Cook GR, Balhorn R, Schmid CW \& Bradbury EM 1990 Isolation of 4 core histones from human sperm chromatin representing a minor subset of somatic histones. Journal of Biological Chemistry $\mathbf{2 6 5}$ 20662-20666.

Govin J, Escoffier E, Rousseaux S, Kuhn L, Ferro M, Thevenon J, Catena R, Davidson I, Garin J, Khochbin S et al. 2007 Pericentric heterochromatin reprogramming by new histone variants during mouse spermiogenesis. Journal of Cell Biology 176 283-294. (doi:10.1083/ jcb.200604141)

Hammoud SS, Nix DA, Zhang H, Purwar J, Carrell DT \& Cairns BR 2009 Distinctive chromatin in human sperm packages genes for embryo development. Nature 460 473-478. (doi:10.1038/nature08162)

Hazzouri M, Rousseaux S, Mongelard F, Usson Y, Pelletier R, Faure AK, Vourc'h C \& Sele B 2000 Genome organization in the human sperm nucleus studied by FISH and confocal microscopy. Molecular Reproduction and Development 55 307-315. (doi:10.1002/(SICI)1098-2795 (200003)55:3<307::AID-MRD9>3.0.CO;2-P)

van der Heijden GW, Derijck AA, Ramos L, Giele $M$, van der Vlag J \& de Boer P 2006 Transmission of modified nucleosomes from the mouse male germline to the zygote and subsequent remodeling of paternal chromatin. Developmental Biology 298 458-469. (doi:10. 1016/j.ydbio.2006.06.051)

van der Heijden GW, Ramos L, Baart EB, van den Berg IM, Derijck AA, van der Vlag J, Martini E \& de Boer P 2008 Sperm-derived histones contribute to zygotic chromatin in humans. BMC Developmental Biology 8 34. (doi:10.1186/1471-213X-8-34)

Huang DW, Sherman LT \& Lempicki RA 2009 Systematic and integrative analysis of large gene lists using DAVID Bioinformatics Resources. Nature Protocols 4 44-57. (doi:10.1038/nprot.2008.211)

Hud NV, Allen MJ, Downing KH, Lee J \& Balhorn R 1993 Identification of the elemental packing unit of DNA in mammalian sperm cells by atomic force microscopy. Biochemical and Biophysical Research Communications 193 1347-1354. (doi:10.1006/bbrc.1993.1773)

Jirtle RL \& Skinner MK 2007 Environmental epigenomics and disease susceptibility. Nature Review Genetics 8 253-262. (doi:10.1038/nrg 2045)

Kim TH, Abdullaev ZK, Smith AD, Ching KA, Loukinov DI, Green RD, Zhang MQ, Lobanenkov VV \& Ren B 2007 Analysis of the vertebrate insulator protein CTCF-binding sites in the human genome. Cell $\mathbf{1 2 8}$ 1231-1245. (doi:10.1016/j.cell.2006.12.048)

McLay DW \& Clarke HJ 2003 Remodelling the paternal chromatin at fertilization in mammals. Reproduction 125 625-633. (doi:10.1530/rep. $0.1250625)$

Nazarov IB, Shlyakhtenko LS, Lyubchenko YL, Zalenskaya IA \& Zalensky AO 2008 Sperm chromatin released by nucleases. Systems Biology in Reproductive Medicine 54 37-46. (doi:10.1080/19396360 701876849)

Ohlsson R, Renkawitz R \& Lobanenkov V 2001 CTCF is a uniquely versatile transcription regulator linked to epigenetics and disease. Trends in Genetics 17 520-527. (doi:10.1016/S0168-9525(01)02366-6)

Palmer DK, O'Day K \& Margolis RL 1990 The centromere specific histone CENP-A is selectively retained in discrete foci in mammalian sperm nuclei. Chromosoma 100 32-36. (doi:10.1007/BF00337600)

Pembrey ME, Bygren LO, Kaati G, Edvinsson S, Northstone K, Sjostrom M \& Golding J 2006 Sex-specific, male-line transgenerational responses in humans. European Journal of Human Genetics 14 159-166. (doi:10. 1038/sj.ejhg.5201538) 
Phillips JE \& Corces VG 2009 CTCF: master weaver of the genome. Cell 137 1194-1211. (doi:10.1016/j.cell.2009.06.001)

Pittoggi C, Renzi L, Zaccagnini G, Cimini D, Degrassi F, Giordano R, Magnano AR, Lorenzini R, Lavia P \& Spadafora C 1999 A fraction of mouse sperm chromatin is organized in nucleosomal hypersensitive domains enriched in retroposon DNA. Journal of Cell Science 112 3537-3548.

Powell D, Cran DG, Jennings C \& Jones R 1990 Spatial organization of repetitive DNA sequences in the bovine sperm nucleus. Journal of Cell Science 97 185-191.

Santos F, Peters AH, Otte AP, Reik W \& Dean W 2005 Dynamic chromatin modifications characterise the first cell cycle in mouse embryos. Developmental Biology 280 225-236. (doi:10.1016/j.ydbio.2005. 01.025)

Tanphaichitr N, Sobhon P, Taluppeth N \& Chalermisarachai P 1978 Basic nuclear proteins in testicular cells and ejaculated spermatozoa in man. Experimental Cell Research 117 347-356. (doi:10.1016/0014-4827(78) 90148-9)

Ward WS \& Coffey DS 1991 DNA packaging and organization in mammalian spermatozoa: comparison with somatic cells. Biology of Reproduction 44 569-574. (doi:10.1095/biolreprod44.4.569)
Weber M, Hellmann I, Stadler MB, Ramos L, Paabo S, Rebhan M \& Schubeler D 2007 Distribution, silencing potential and evolutionary impact of promoter DNA methylation in the human genome. Nature Genetics 39 457-466. (doi:10.1038/ng1990)

Wykes SM \& Krawetz SA 2003 The structural organization of sperm chromatin. Journal of Biological Chemistry 278 29471-29477. (doi:10. 1074/jbc.M304545200)

Zalenskaya IA, Bradbury EM \& Zalensky AO 2000 Chromatin structure of telomere domain in human sperm. Biochemical and Biophysical Research Communications 279 213-218. (doi:10.1006/bbrc.2000.3917)

Zalensky AO, Allen MJ, Kobayashi A, Zalenskaya IA, Balhorn R \& Bradbury EM 1995 Well-defined genome architecture in the human sperm nucleus. Chromosoma 103 577-590. (doi:10.1007/BF00357684)

Received 23 December 2010

First decision 7 February 2011

Revised manuscript received 4 April 2011

Accepted 21 April 2011 